\title{
Thermocline state change in the eastern equatorial Pacific during the late Pliocene/early Pleistocene intensification of Northern Hemisphere glaciation
}

\author{
Kim Alix Jakob ${ }^{1}$, Jörg Pross ${ }^{1}$, Christian Scholz ${ }^{1}$, Jens Fiebig ${ }^{2}$, and Oliver Friedrich ${ }^{1}$ \\ ${ }^{1}$ Institute of Earth Sciences, Heidelberg University, 69120 Heidelberg, Germany \\ ${ }^{2}$ Institute of Geosciences, Goethe University Frankfurt, 60438 Frankfurt, Germany
}

Correspondence: Kim Alix Jakob (kim.jakob@geow.uni-heidelberg.de)

Received: 16 November 2017 - Discussion started: 20 November 2017

Revised: 9 April 2018 - Accepted: 9 July 2018 - Published: 25 July 2018

\begin{abstract}
The late Pliocene/early Pleistocene intensification of Northern Hemisphere glaciation (iNHG) $\sim 2.5$ million years ago (marine isotope stages, MIS, 100-96) stands out as an important tipping point in Earth's climate history, which strongly influenced oceanographic and climatic patterns including trade wind and upwelling strength in the eastern equatorial Pacific (EEP). The thermocline depth in the EEP, in turn, plays a pivotal role in the Earth's climate system: small changes in its depth associated with short-term climate phenomena such as the El Niño-Southern Oscillation can affect surface-water properties and the ocean-atmosphere exchange. However, thermocline dynamics in the EEP during the iNHG still remain unclear. While numerous studies have suggested a link between a thermocline shoaling in the EEP and Northern Hemisphere ice growth, other studies have indicated a stable thermocline depth during the iNHG; consequently, a causal relationship between thermocline dynamics and ice-sheet growth has been excluded. In light of these contradictory views, we have generated geochemical (planktic foraminiferal $\delta^{18} \mathrm{O}, \delta^{13} \mathrm{C}$ and $\mathrm{Mg} / \mathrm{Ca}$ ), sedimentological (sand accumulation rates) and faunal (abundance data of thermocline-dwelling foraminifera) records for Ocean Drilling Program Site 849 located in the central region of the EEP. Our records span the interval from $\sim 2.75$ to $2.4 \mathrm{Ma}$ (MIS G7-95), which is critical for understanding thermocline dynamics during the final phase of the iNHG. Our new records document a thermocline shoaling from $\sim$ 2.64 to $2.55 \mathrm{Ma}$ (MIS G2-101) and a relatively shallow thermocline from $\sim 2.55 \mathrm{Ma}$ onwards (MIS 101-95). This indicates a state change in thermocline depth at Site 849 shortly before the final phase of the iNHG. Ultimately, our data sup-
\end{abstract}

port the hypothesis that (sub-)tropical thermocline shoaling may have contributed to the development of large Northern Hemisphere ice sheets.

\section{Introduction}

The onset and intensification of Northern Hemisphere glaciation during the late Pliocene and early Pleistocene $(\sim 3.6$ 2.4 Ma; Mudelsee and Raymo, 2005) is part of a long-term cooling trend following the mid-Piacenzian warm period. The glacial corresponding to marine isotope stage (MIS) G6 $(\sim 2.7 \mathrm{Ma})$ is often considered to mark the onset of largescale glaciation in the Northern Hemisphere, as it is characterized by the first occurrence of ice-rafted debris in the North Atlantic Ocean (Bartoli et al., 2006; Bailey et al., 2013). The first culmination in Northern Hemisphere ice buildup occurred at $\sim 2.5 \mathrm{Ma}$ as documented by the first three large-amplitude $\left(\sim 1 \%\right.$ in the benthic $\delta^{18} \mathrm{O}$ record) glacial-interglacial cycles (MIS 100-96) that indicate substantial waxing and waning of ice sheets (Lisiecki and Raymo, 2005). At that time, ice rafting became widespread across the North Atlantic Ocean (Shackleton et al., 1984; Naafs et al., 2013). This so-called "intensification of Northern Hemisphere glaciation" (iNHG) represents an important tipping point in Earth's climate history. It strongly influenced oceanographic and climatic patterns worldwide, affecting, for example, the amount of biological production in the eastern equatorial Pacific Ocean (EEP) (Etourneau et al., 2010; Jakob et al., 2016) - a region that exerts a strong influence on the Earth's climate system through its effects on the global 
carbon and nutrient cycles (e.g., Schlitzer, 2004; Takahashi et al., 2009).

Within the EEP, the position of the thermocline in the water column bears important consequences for the Earth's climate system. Today, it is poised at shallow depths. As a consequence, small changes in its depth through east-west tilting regulated by short-term climate phenomena such as the El Niño-Southern Oscillation can affect surface-water properties and ocean-atmosphere exchange processes (Fedorov et al., 2004; Ma et al., 2013). In general, proxy records and modeling results consistently document a long-term shoaling of the thermocline in the EEP and other (sub-)tropical upwelling regions throughout the Plio-Pleistocene (Wara et al., 2005; Fedorov et al., 2006; Steph et al., 2006a, 2010; Dekens et al., 2007; Ford et al., 2012). However, the dynamics of the thermocline in the EEP and its potential links to the iNHG currently remained enigmatic. Some studies have inferred that the thermocline depth reached a critical threshold at $\sim 3 \mathrm{Ma}$, which allowed trade winds to deliver cool waters from below the thermocline to the surface in (sub-)tropical upwelling regions such as the EEP (Fedorov et al., 2006; Dekens et al., 2007). The timing led to the hypothesis that thermocline shoaling and the development of the EEP "cold tongue" (Wyrtki, 1981) were necessary preconditions for the iNHG, as they reduced poleward atmospheric heat transport (Cane and Molnar, 2001). However, other studies only identified fundamental shifts in the thermocline depth prior to $\sim 3.5 \mathrm{Ma}$ (Wara et al., 2005; Steph et al., 2006a, 2010; Ford et al., 2012), which would imply that the thermocline depth in the EEP did not play an important role in the development of large-scale glaciation in the Northern Hemisphere. In light of these contradictory views, and to ultimately shed new light on potential links between low-latitude thermocline dynamics and high-latitude ice-sheet buildup, we investigated thermocline state changes for Ocean Drilling Program (ODP) Site 849 in the EEP during the final phase of the late Pliocene/early Pleistocene iNHG $(\sim 2.75$ to $2.4 \mathrm{Ma}$, MIS G7-95).

\section{Study area and study site}

\subsection{The eastern equatorial Pacific}

The EEP has considerable relevance for the Earth's atmospheric and marine carbon budget (Toggweiler and Sarmiento, 1985; Takahashi et al., 2009), and simultaneously exerts strong control on oceanographic and climatic circulation patterns (Fedorov and Philander, 2000; Pennington et al., 2006). Today, as a part of the tropical Pacific Walker circulation, westward-blowing trade winds induce a year-round upwelling of cold waters from below the thermocline to the surface in the EEP. This results in a thin, nutrient-enriched and relatively cold ( $\sim 23^{\circ} \mathrm{C}$; Locarnini et al., 2013$)$ mixed layer, the so-called EEP “cold tongue" (Wyrtki, 1981) (Fig. 1a, b). In today's oceans, this upwelling system supports more than
$10 \%$ of the global biological production (Pennington et al., 2006). Relatively high primary productivity rates result in exceptionally high sedimentation rates, which have amounted to up to $3.0 \mathrm{~cm} \mathrm{kyr}^{-1}$ during the past $5 \mathrm{Myr}$ (Mayer et al., 1992; Mix et al., 1995).

The EEP stands out as an ideal natural laboratory for studying the dynamics of the tropical thermocline: the shallow depth of the thermocline in the present-day EEP upwelling system $(\sim 50 \mathrm{~m}$; Wang et al., 2000) (Fig. 1c) means that even small changes in its depth can affect surface-water properties, such as temperature or nutrient content, which can be ideally reconstructed from sediments underneath the "cold tongue". Thereby, the high sedimentation rates allow for the acquisition of proxy records at a high temporal resolution compared to areas outside the EEP upwelling zone.

\subsection{ODP Site 849}

To reconstruct changes in the thermocline depth in the EEP we focused on sediments from ODP Leg 138 Site 849 (coordinates: $0^{\circ} 11^{\prime} \mathrm{N}, 110^{\circ} 31^{\prime} \mathrm{W}$; present-day water depth: $3851 \mathrm{~m}$; Mayer et al., 1992) (Fig. 1a, b). This site was selected because of (i) its position within the equatorial "cold tongue", west of the East Pacific Rise in the open ocean, which makes it less prone to continental influence compared to sites east of the East Pacific Rise (Mix et al., 1995); (ii) the good preservation of foraminifera (Jakob et al., 2016, 2017) despite the fact that the present-day water depth at Site 849 is close to the lysocline (Adelseck and Anderson, 1978; Berger et al., 1982); and (iii) the high sedimentation rates (2.7 $\mathrm{cm} \mathrm{kyr}^{-1}$ for our study interval; Jakob et al., 2017) with continuous sedimentation (Mayer et al., 1992).

\section{Investigated foraminiferal species}

The geochemical and faunal records generated in this study (for details see Sect. 4) are based on the planktic foraminiferal species Globigerinoides ruber (white, sensu stricto), Globorotalia crassaformis, Globorotalia menardii and Globorotalia tumida; the presumed calcification depths of these species in the EEP, as briefly elaborated upon in the following, are compiled in Fig. 1c. Globigerinoides ruber generally inhabits and calcifies in the mixed layer and is typically considered to represent surface-water conditions (Fairbanks et al., 1982; Wang, 2000; Dekens et al., 2002; Steph et al., 2009, and references therein). Globorotalia menardii and Globorotalia tumida are found in the EEP at depths of $\sim 25$ 70 and $\sim 50-125 \mathrm{~m}$, respectively, typically in intermediatethermocline waters (Fairbanks et al., 1982; Watkins et al., 1998; Faul et al., 2000). Globorotalia crassaformis inhabits the bottom of the thermocline (Niebler et al., 1999; Regenberg et al., 2009; Steph et al., 2009, and references therein), and has a rather constant calcification depth as opposed to other deep-dwelling foraminiferal species (Cléroux and Lynch-Stieglitz, 2010). Whilst its exact calcification depth 

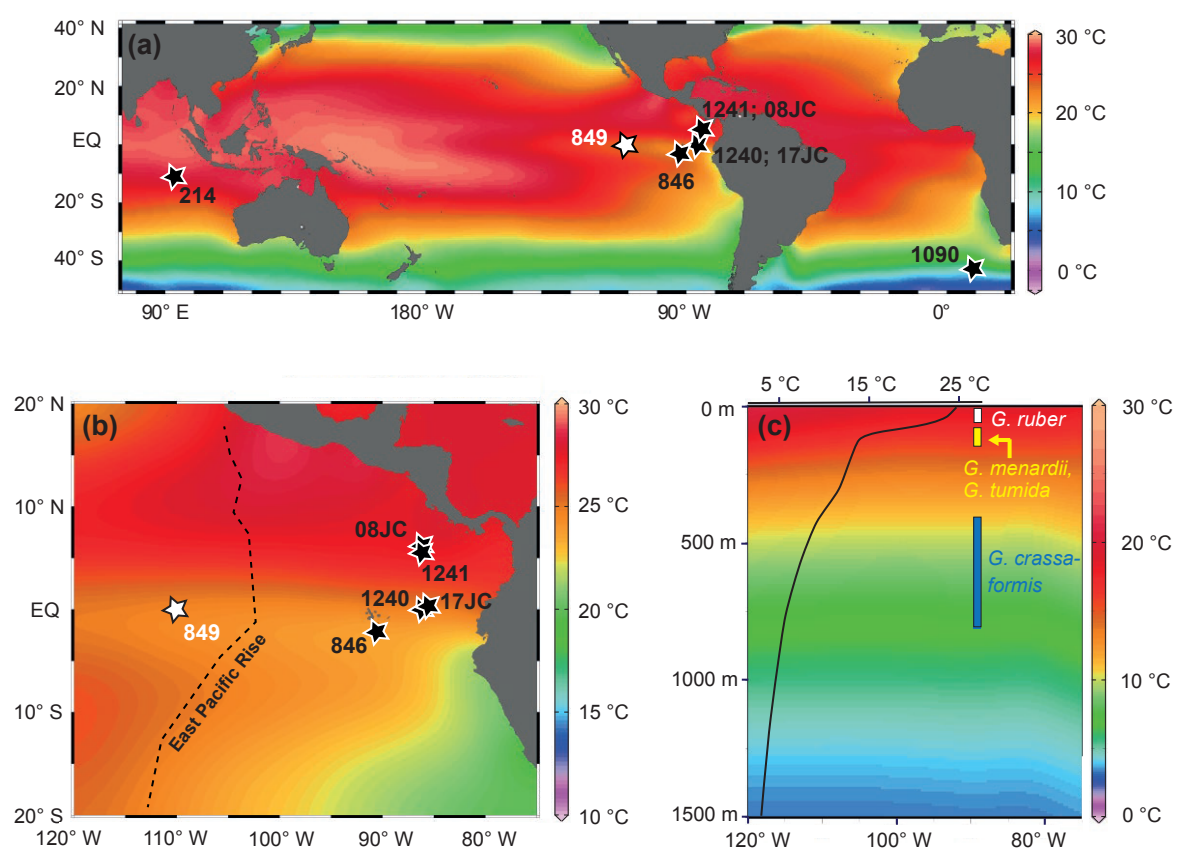

Figure 1. Location of the study area and present-day temperature profile at the study site. (a) Map indicating the location of the study site (ODP Site 849; white) and other sites mentioned in the text (black). (b) Map showing the location of Site 849 in the EEP "cold tongue" (white) and other east Pacific sites mentioned in the text (black). Colors in (a) and (b) denote mean annual surface-water temperatures. (c) Mean annual temperature profile for Site 849 showing the position of the thermocline. Calcification depths of foraminiferal species analyzed in this study are indicated by white (G. ruber), yellow (G. menardii and G. tumida) and blue (G. crassaformis) bars (because the calcification depth of G. crassaformis in the EEP remains unclear, we show its calcification depth range identified for the (sub-)tropical Atlantic and the Caribbean Sea; see Sect. 3 for details). Maps are from the World Ocean Atlas (Locarnini et al., 2013).

in the EEP remains unclear, $\delta^{18} \mathrm{O}$ values of $G$. crassaformis from the (sub-)tropical Atlantic and the Caribbean Sea suggest that this species typically calcifies at water depths between $\sim 400$ and $800 \mathrm{~m}$ (Steph et al., 2006b, 2009; Regenberg et al., 2009; Cléroux et al., 2013).

\section{Material and methods}

To reconstruct the thermocline depth for the final phase of the late Pliocene/early Pleistocene iNHG from $\sim 2.75$ to $2.4 \mathrm{Ma}$ (MIS G7-95), we integrate new and previously published proxy records from ODP Site 849 (Fig. 1; Table 1). In particular, we combine planktic (both sea surfaceand thermocline-dwelling) foraminiferal geochemical $\left(\delta^{18} \mathrm{O}\right.$, $\delta^{13} \mathrm{C}$ and $\mathrm{Mg} / \mathrm{Ca}$ ) proxy records with sedimentological (sand accumulation rates) and faunal (abundance data of thermocline-dwelling foraminiferal species) information.

\subsection{Sample material}

To obtain geochemical, faunal and sedimentological information for Site 849, 374 samples were investigated along the primary shipboard splice (Mayer et al., 1992) from cores $849 \mathrm{C}-7 \mathrm{H}-1-80 \mathrm{~cm}$ to $849 \mathrm{C}-7 \mathrm{H}-2-21 \mathrm{~cm}$ and $849 \mathrm{D}-6 \mathrm{H}-$ $5-102 \mathrm{~cm}$ to $849 \mathrm{D}-7 \mathrm{H}-5-57 \mathrm{~cm}$ (77.02-67.78 m composite depth, $m$ c.d.). Based on the age model of Jakob et al. (2017), this interval spans from $\sim 2.75$ to $2.4 \mathrm{Ma}$ (MIS G7-95). Samples with a volume of $20 \mathrm{~cm}^{3}$ were investigated at $2 \mathrm{~cm}$ intervals, which yielded a temporal resolution of $\sim 750$ years. The sample material was dried, weighed and washed over a $63 \mu \mathrm{m}$ sieve.

Foraminiferal geochemical records $\left(\delta^{18} \mathrm{O}, \quad \delta^{13} \mathrm{C}\right.$ and $\mathrm{Mg} / \mathrm{Ca}$ ) of the deep-thermocline-dwelling species G. crassaformis and the surface-dwelling species $G$. ruber, as well as sand accumulation rates were generated from the full sample set (with a temporal resolution of $\sim 750$ years). From these measurements surface to thermocline $\delta^{18} \mathrm{O}, \delta^{13} \mathrm{C}$ and $\mathrm{Mg} / \mathrm{Ca}$ gradients were calculated. Abundance counts of both deep-thermocline- (G. crassaformis) and intermediatethermocline-dwelling species (G. menardii and G. tumida) were conducted every $20 \mathrm{~cm}$ (with a temporal resolution of $\sim 7.5 \mathrm{kyr})$.

For G. crassaformis, we generated new $\delta^{18} \mathrm{O}, \delta^{13} \mathrm{C}$ and $\mathrm{Mg} / \mathrm{Ca}$ records, except for the interval from $\sim 2.65$ to 2.4 Ma for which $\delta^{13} \mathrm{C}$ values had already been published by Jakob et al. (2016). For this purpose, an average of 15 individuals per sample was picked from the 315 to $400 \mu \mathrm{m}$ fraction. This size fraction was selected to keep ontogenetic effects as small as possible (Elderfield et al., 2002; Friedrich 
Table 1. Compilation of the geochemical datasets from ODP Site 849 evaluated in this study. The number of samples indicates the total amount of samples processed (dried, weighed, washed) during each study, while the number of geochemical datapoints is somewhat lower depending on the availability of foraminiferal (G. crassaformis and G. ruber) material in each sample.

\begin{tabular}{|c|c|c|c|c|c|}
\hline Foraminiferal species & Size fraction & Proxy & Interval & $\begin{array}{l}\text { No. of samples } \\
\text { (datapoints) }\end{array}$ & Reference \\
\hline \multirow{4}{*}{$\begin{array}{l}\text { G. crassaformis } \\
\text { (sinistral- and dextral- } \\
\text { coiling) }\end{array}$} & \multirow[t]{2}{*}{$315-400 \mu \mathrm{m}$} & \multirow[t]{2}{*}{$\delta^{13} \mathrm{C}$} & $\begin{array}{l}\text { 74.17-67.78 m c.d. } \\
(\sim 2.65-2.4 \mathrm{Ma} ; \text { MIS G1-95) }\end{array}$ & $229(215)$ & Jakob et al. (2016) \\
\hline & & & $\begin{array}{l}\text { 77.02-74.19 m c.d. } \\
(\sim 2.75-2.65 \mathrm{Ma} ; \text { MIS G7-G2) }\end{array}$ & $145(43)$ & this study \\
\hline & $315-400 \mu \mathrm{m}$ & $\delta^{18} \mathrm{O}$ & $\begin{array}{l}77.02-67.78 \text { m c.d. } \\
(\sim 2.75-2.4 \mathrm{Ma} ; \text { MIS G7-95) }\end{array}$ & $374(258)$ & this study \\
\hline & $315-400 \mu \mathrm{m}$ & $\mathrm{Mg} / \mathrm{Ca}$ & $\begin{array}{l}77.02-67.78 \text { m c.d. } \\
(\sim 2.75-2.4 \mathrm{Ma} ; \text { MIS G7-95) }\end{array}$ & $374(247)$ & this study \\
\hline \multirow[t]{4}{*}{$\begin{array}{l}\text { G. ruber } \\
\text { (white, sensu stricto) }\end{array}$} & \multirow[t]{2}{*}{$250-315 \mu \mathrm{m}$} & \multirow[t]{2}{*}{$\delta^{13} \mathrm{C}$} & $\begin{array}{l}\text { 74.17-67.78 m c.d. } \\
(\sim 2.65-2.4 \mathrm{Ma} ; \text { MIS G1-95) }\end{array}$ & $229(225)$ & Jakob et al. (2016) \\
\hline & & & $\begin{array}{l}77.02-74.19 \text { m c.d. } \\
(\sim 2.75-2.65 \mathrm{Ma} ; \text { MIS G7-G2) }\end{array}$ & 145 (137) & this study \\
\hline & $250-315 \mu \mathrm{m}$ & $\delta^{18} \mathrm{O}$ & $\begin{array}{l}\text { 77.02-67.78 m c.d. } \\
(\sim 2.75-2.4 \mathrm{Ma} ; \text { MIS G7-95) }\end{array}$ & $374(362)$ & Jakob et al. (2017) \\
\hline & $200-250 \mu \mathrm{m}$ & $\mathrm{Mg} / \mathrm{Ca}$ & $\begin{array}{l}\text { 77.02-67.78 m c.d. } \\
(\sim 2.75-2.4 \mathrm{Ma} ; \text { MIS G7-95) }\end{array}$ & $374(316)$ & Jakob et al. (2017) \\
\hline
\end{tabular}

et al., 2012) but at the same time to allow for a sufficient number of G. crassaformis tests per sample. Moreover, the 315$400 \mu \mathrm{m}$ fraction ensured the highest comparability to previous geochemical records of this species (e.g., Karas et al., 2009; Jakob et al., 2016). Tests for $\delta^{18} \mathrm{O}$ and $\mathrm{Mg} / \mathrm{Ca}$ analyses were cracked, homogenized and split into two subsamples. For G. crassaformis, both sinistral- and dextral-coiling specimens occur at Site 849; geochemical data were preferentially measured on tests with the most abundant coiling direction (sinistral). However, sinistral-coiling specimens do not occur continuously across our study interval. Thus, dextral-coiling tests were used for some intervals (in particular from $\sim 2.46$ to $2.43 \mathrm{Ma}(69.84-69.04 \mathrm{~m} \mathrm{c.d}$.) and from $\sim 2.51$ to $2.50 \mathrm{Ma}(70.85-70.68 \mathrm{~m} \mathrm{c.d}$.)). The occurrence of dextral- versus sinistral-coiling $G$. crassaformis specimens is random rather than following a specific cyclicity. Separate measurements of geochemical parameters $\left(\delta^{13} \mathrm{C}, \delta^{18} \mathrm{O}\right.$, $\mathrm{Mg} / \mathrm{Ca}$ ) on sinistral- and dextral-coiling specimens from the same samples have demonstrated that the reconstructed values are independent of the coiling directions (see also Jakob et al., 2016).

The number of G. crassaformis individuals in the investigated size fraction $(315-400 \mu \mathrm{m})$ was too low to allow for geochemical analyses in specific intervals. These intervals were from 2.68 to $2.65 \mathrm{Ma}(75.39-74.65 \mathrm{~m}$ c.d. corresponding to MIS G3) and from 2.73 to $2.69 \mathrm{Ma}(77.02-75.79 \mathrm{~m} \mathrm{c.d}$. corresponding to MIS G7-G5). We decided not to fill these gaps using another size fraction because (i) this might have biased our $\mathrm{Mg} / \mathrm{Ca}$ and stable isotope records due to ontogenetic effects (Elderfield et al., 2002; Friedrich et al., 2012), and (ii) the abundance of $G$. crassaformis specimens $<315 \mu \mathrm{m}$ was also too low for geochemical analyses in most of the samples where the 315-400 $\mu \mathrm{m}$ G. crassaformis size fraction was absent (see Sect. 5.4.2 for details).

For G. ruber, the previously published Mg / Ca-based seasurface temperature (SST) and $\delta^{18} \mathrm{O}$ datasets of Jakob et al. (2017) were augmented by $\delta^{13} \mathrm{C}$ data, except for the interval from $\sim 2.65$ to $2.4 \mathrm{Ma}$ for which $\delta^{13} \mathrm{C}$ values have already been published by Jakob et al. (2016). For this purpose, an average of 12 specimens was picked from the 250$315 \mu \mathrm{m}$ size fraction (i.e., the fraction also used in Jakob et al., 2016). An overview of all geochemical datasets evaluated in this study is presented in Table 1.

\subsection{Analytical methods}

\subsubsection{Foraminiferal preservation}

The preservation of planktic foraminiferal (G. crassaformis and $G$. ruber) tests used for geochemical analyses was examined using scanning electron microscope (SEM) images of selected specimens from both glacial and interglacial intervals. Close-up views were taken using a LEO 440 SEM at the Institute of Earth Sciences, Heidelberg University. 


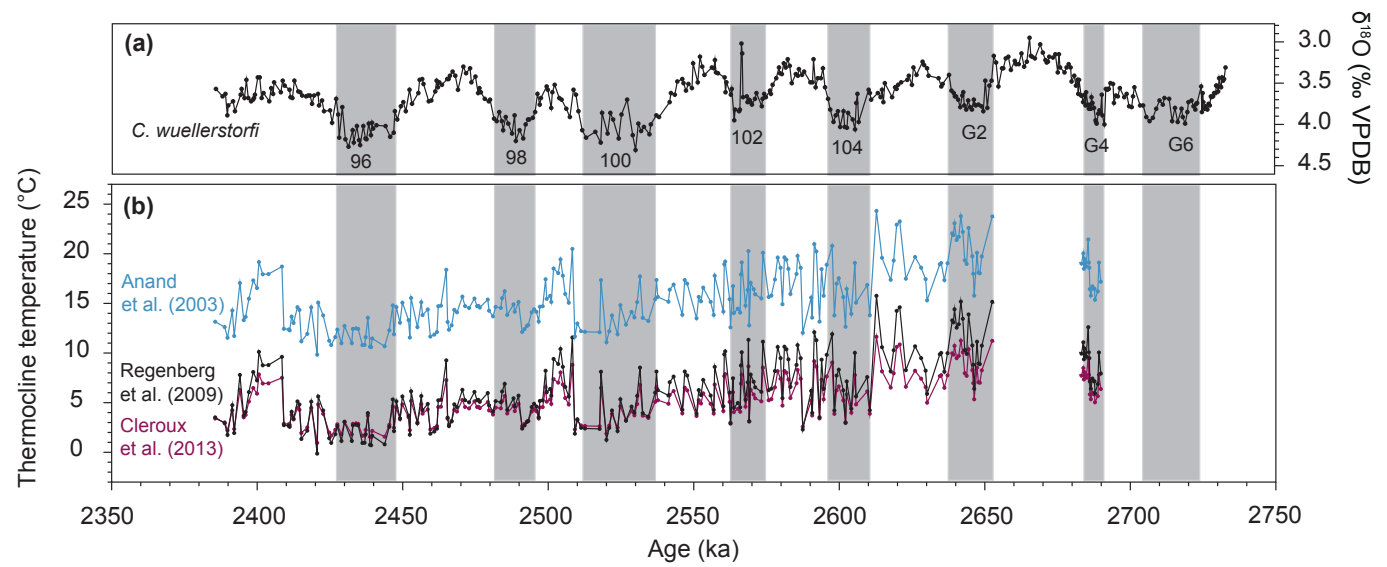

Figure 2. Species-specific conversions of $\mathrm{Mg} / \mathrm{Ca}$ ratios to temperature for G. crassaformis. (a) Benthic foraminiferal (C. wuellerstorfi) $\delta^{18} \mathrm{O}$ stratigraphy (Jakob et al., 2017). (b) Comparison of the different species-specific $\mathrm{Mg} / \mathrm{Ca}$ to temperature conversions of Cléroux et al. (2013; red), Regenberg et al. (2009; black) and Anand et al. (2003; blue) applied to G. crassaformis Mg / Ca values from Site 849 for $\sim 2.75$ to $2.4 \mathrm{Ma}$. Gaps in the dataset for 2.68-2.65 Ma (MIS G3) and 2.73-2.69 Ma (MIS G7-G5) are due to a lack of G. crassaformis specimens in the investigated size fraction $(315-400 \mu \mathrm{m})$. Grey bars highlight glacial periods.

\subsubsection{Stable isotope analyses}

Oxygen and carbon isotopes of G. ruber and G. crassaformis were analyzed using a Thermo Finnigan MAT253 gas source mass spectrometer equipped with a Gas Bench II at the Institute of Geosciences, Goethe University Frankfurt. Values are reported relative to the Vienna Pee Dee Belemnite (VPDB) standard through the analysis of an in-house standard calibrated to NBS-19. The precision of the $\delta^{18} \mathrm{O}$ and $\delta^{13} \mathrm{C}$ analyses is better than 0.08 and $0.06 \%$ (at $1 \sigma$ level), respectively. $\delta^{13} \mathrm{C}$ values of $G$. ruber reported herein were adjusted for the species-specific offset from equilibrium precipitation via the addition of $+0.94 \%$ (Spero et al., 2003), while measured $\delta^{18} \mathrm{O}$ values of $G$. ruber were considered to approximate equilibrium precipitation (Koutavas and LynchStieglitz, 2003) and were not adjusted. For G. crassaformis we simply report the measured values, as laboratory investigations on $\delta^{13} \mathrm{C}$ and $\delta^{18} \mathrm{O}$ fractionation for this species are still lacking.

\subsubsection{Mg/ Ca analyses}

Samples of G. crassaformis for $\mathrm{Mg} / \mathrm{Ca}$ analyses were carefully cleaned to remove clay minerals, organic material and re-adsorbed contaminants following the protocol of Barker et al. (2003) but omitting reductive cleaning. However, for selected samples reductive cleaning was also applied (see Sect. 5.2); a mixture of hydrazine, ammonium hydroxide and ammonium citrate was used as a reductive reagent. Analyses were carried out with an Agilent 720 inductively coupled plasma-optical emission spectrometer at the Institute of Earth Sciences, Heidelberg University. Reported Mg / Ca values were normalized relative to the ECRM 752-1 standard reference value of $3.762 \mathrm{mmol} \mathrm{mol}^{-1}$ (Greaves et al.,
2008). To ensure instrumental precision, an internal consistency standard was monitored at least every 20 samples. Based on replicate measurements, a standard deviation for $\mathrm{Mg} / \mathrm{Ca}$ of $\pm 0.02 \mathrm{mmol} \mathrm{mol}^{-1}$ (corresponding to $\pm 0.12^{\circ} \mathrm{C}$ ) was obtained. To identify possible contamination by clay particles or diagenetic coatings that might affect foraminiferal $\mathrm{Mg} / \mathrm{Ca}$ ratios (Barker et al., 2003), elemental ratios of $\mathrm{Al} / \mathrm{Ca}, \mathrm{Fe} / \mathrm{Ca}$ and $\mathrm{Mn} / \mathrm{Ca}$ were screened (see Sect. 5.2).

\subsubsection{Paleotemperature reconstruction}

Species-specific conversions of $\mathrm{Mg} / \mathrm{Ca}$ to temperature for G. crassaformis were only calibrated based on samples from the Atlantic Ocean (Anand et al., 2003; Regenberg et al., 2009; Cléroux et al., 2013). These equations yield the same trend and amplitudes when applied to G. crassaformis $\mathrm{Mg} / \mathrm{Ca}$ values from Site 849, but differ with regard to absolute values (Fig. 2). We converted $\mathrm{Mg} / \mathrm{Ca}$ ratios of $G$. crassaformis into temperature following the species-specific equation of Cléroux et al. (2013) for the following two reasons: (i) the selected calibration is based on specimens with a grain size of 355-425 $\mu \mathrm{m}$, which matches the size fraction used in our study $(315-400 \mu \mathrm{m})$ better than the other available equations; and (ii) the $\mathrm{Mg} / \mathrm{Ca}$ range of $G$. crassaformis from Site $849\left(\sim 1-3 \mathrm{mmol} \mathrm{mol}^{-1}\right)$ fits best to the calibration range $\left(\sim 1-2 \mathrm{mmol} \mathrm{mol}^{-1}\right)$ of the equation from Cléroux et al. (2013) compared to the other equations.

As the equation of Cléroux et al. (2013) is based on oxidative and reductive cleaning of foraminiferal tests, and only oxidative cleaning has been applied to Site 849 samples, the measured $\mathrm{Mg} / \mathrm{Ca}$ values had to be reduced by $10 \%$ (Barker et al., 2003). The pooled uncertainty in the temperature record is $\pm 0.94^{\circ} \mathrm{C}$ (analytical error of 
$\pm 0.02 \mathrm{mmol} \mathrm{mol}^{-1}$, corresponding to $\pm 0.12{ }^{\circ} \mathrm{C}$, and a calibration error of $\pm 0.82^{\circ} \mathrm{C}$; Cléroux et al., 2013).

\subsubsection{Abundance counts}

Following the approach of Sexton and Norris (2008), abundance counts of deep-thermocline-dwelling (G. crassaformis, both sinistral- and dextral-coiling specimens) and intermediate-thermocline-dwelling ( $G$. tumida and $G$. menardii) species (Fig. 1c) were generated for the $>250 \mu \mathrm{m}$ size fraction of Site 849 samples. The $>250 \mu \mathrm{m}$ size fraction was split down to at least 400 individual planktic foraminifera using a microsplitter. Abundance counts were converted to mass accumulation rates using linear sedimentation rates and dry bulk density data (calculated from highresolution GRAPE density shipboard measurements, IODP JANUS database; Mayer et al., 1992) following the methodology described in Jakob et al. (2016).

\subsubsection{Sand accumulation rates}

The sand accumulation rates available for the MIS G1-95 ( 2.65-2.4 Ma) interval from Site 849, as presented in Jakob et al. (2016), were extended back to MIS G7 $(\sim 2.75 \mathrm{Ma})$ in this study. They were calculated using linear sedimentation rates, dry bulk density data (calculated from highresolution GRAPE density shipboard measurements, IODP JANUS database; Mayer et al., 1992) and the portion of the $>63 \mu \mathrm{m}$ sand fraction following the approach described in Jakob et al. (2016).

\section{Results and discussion}

\subsection{Foraminiferal test preservation at Site 849}

Shipboard investigations on core catchers originally reported a poor preservation of planktic foraminiferal tests at Site 849 (Mayer et al., 1992). However, these observations do not apply to the samples from our study interval. Instead, SEM images of both glacial and interglacial G. crassaformis and G. ruber specimens consistently show well-preserved fine features such as delicate spines, pore channels and a layered wall structure, in addition to a lack of secondary calcite or crusts on test surfaces (Fig. 3). This indicates that test preservation is consistently sufficient for the acquisition of high-quality geochemical data for both species throughout the study interval. A low planktic foraminiferal fragmentation index (Jakob et al., 2017) and large numbers of wellpreserved, although typically less resistant, specimens such as Globigerinoides (Dittert et al., 1999) (Fig. 3g-l) further confirms this interpretation, and indicates that dissolution has not considerably affected foraminiferal tests.

\subsection{Assessment of contamination and diagenetic effects on $\mathrm{Mg} / \mathrm{Ca}$ ratios of $\mathrm{G}$. crassaformis}

$\mathrm{Al} / \mathrm{Ca}, \mathrm{Fe} / \mathrm{Ca}$ and $\mathrm{Mn} / \mathrm{Ca}$ ratios $>0.1 \mathrm{mmol} \mathrm{mol}^{-1}$ are typically considered to indicate the presence of detrital clay, Fe-rich coatings and Mn-rich overgrowth, respectively. Such contamination might have biased the measured $\mathrm{Mg} / \mathrm{Ca}$ ratios (Barker et al., 2003). In most of our samples the content of $\mathrm{Al}$ was below the detection limit, arguing against the presence of detrital clay. With the exception of a few samples, $\mathrm{Fe} / \mathrm{Ca}$ values also do not exceed the critical value of $0.1 \mathrm{mmol} \mathrm{mol}^{-1}$, which indicates no contamination by $\mathrm{Fe}-$ rich overgrowth (Fig. 4a). The lack of a statistically significant correlation between $\mathrm{Mg} / \mathrm{Ca}$ and $\mathrm{Fe} / \mathrm{Ca}$ ratios $\left(r^{2}=\right.$ $0.17, p<0.01)$ further supports this finding.

However, measured $\mathrm{Mn} / \mathrm{Ca}$ ratios were above the $0.1 \mathrm{mmol} \mathrm{mol}^{-1}$ threshold, which might indicate Mn-rich overgrowth on the analyzed tests (Fig. 4b). Reductive cleaning (in addition to the standard cleaning procedure applied to Site 849 samples; see Sect. 4.2.3) performed on selected samples shows $\sim 40-45 \%$ lower $\mathrm{Mn} / \mathrm{Ca}$ values compared to values derived from oxidative cleaning alone. This indicates that at least two different $\mathrm{Mn}$ phases coexist on $G$. crassaformis test surfaces. A similar observation has been made for the thermocline-dwelling species Neogloboquadrina dutertrei from the nearby ODP Site 1240, located in the Panama Basin. In this study, Mn-rich phases not removed through oxidative cleaning are hypothesized to arise from "kutnahorite-like" carbonates or Mn oxyhydroxide (Pena et al., 2005) - Mn phases that may also exist on G. crassaformis test surfaces at Site 849. Indeed, our data show a weak correlation between the $\mathrm{Mg} / \mathrm{Ca}$ and $\mathrm{Mn} / \mathrm{Ca}$ ratios for $G$. crassaformis samples $\left(r^{2}=0.44, p<0.01\right)$, which might indicate a bias of the measured $\mathrm{Mg} / \mathrm{Ca}$ ratios due to a Mn-rich overgrowth. However, we note that SEM images argue against the existence of any kind of overgrowth (Fig. 3). Diagenetic overgrowth usually has a $\mathrm{Mg} / \mathrm{Mn}$ ratio of $\sim 0.1 \mathrm{~mol} \mathrm{~mol}^{-1}$ (Barker et al., 2003, and references therein). If an unrealistically high $\mathrm{Mg} / \mathrm{Mn}$ ratio of 1 in the diagenetic overgrowth is assumed, this might change temperature estimates by $\sim 0.5^{\circ} \mathrm{C}$ on average; however, we note that this would not affect the overall shape of the $\mathrm{Mg} / \mathrm{Ca}-$ based temperature record (Fig. 4c, d). Therefore, we conclude with reasonable certainty that early diagenetic overprinting has no significant impact on the interpretation of our data, although we cannot rule out the possibility of diagenetic changes in G. crassaformis tests because of significantly enriched $\mathrm{Mn} / \mathrm{Ca}$ ratios.

\subsection{Geochemical records of G. crassaformis and G. ruber at Site 849}

In warm tropical waters, where seasonal climate variability is low, geochemical signatures of the investigated foraminiferal species are typically considered not to be seasonally biased 


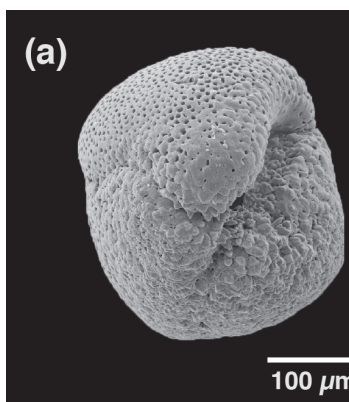

(b)

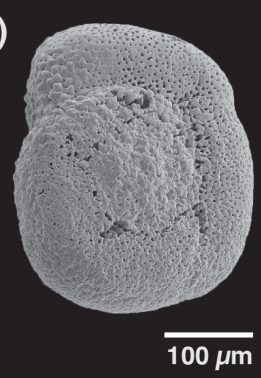

(d)

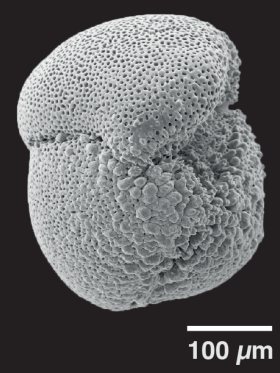

(g)

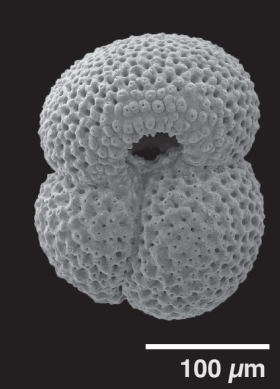

(j)

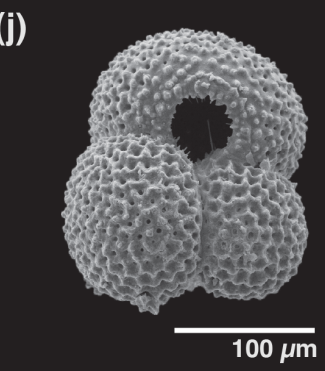

(e)

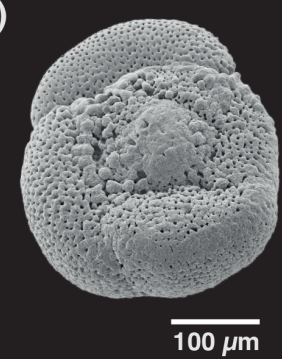

(h)

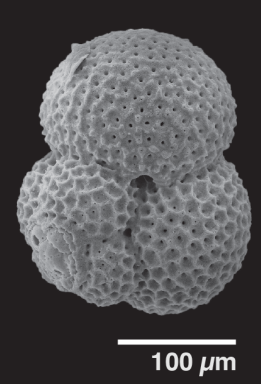

(k)

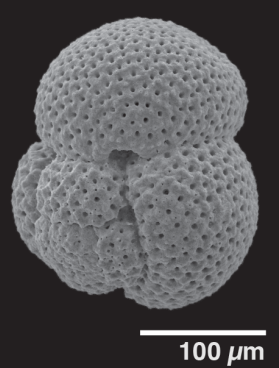

(c)

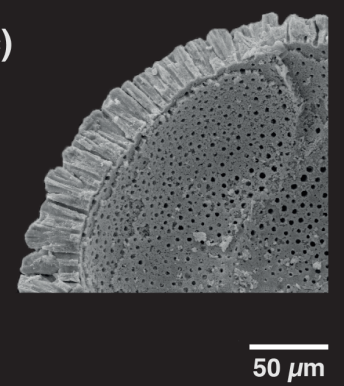

(f)

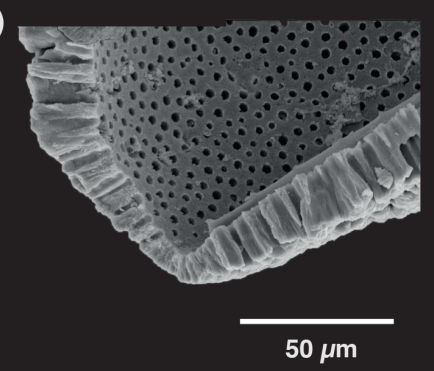

(i)

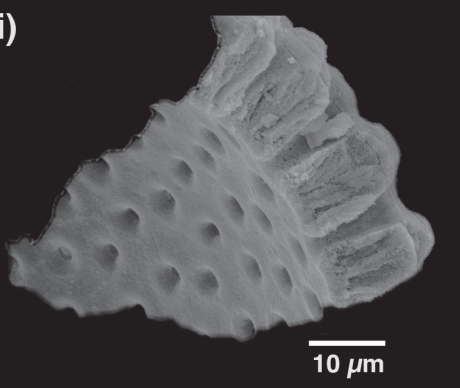

(l)

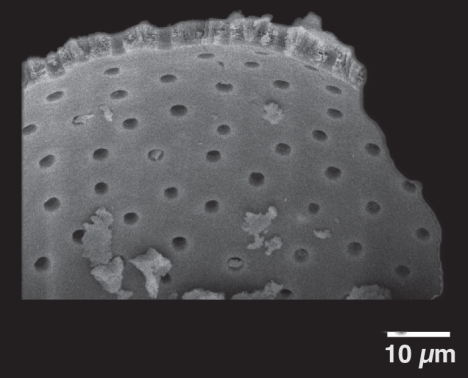

Figure 3. Scanning electron micrographs of Globorotalia crassaformis and Globigerinoides ruber from Site 849. Both glacial (a-c, g-i) and interglacial $(\mathbf{d}-\mathbf{f}, \mathbf{j}-\mathbf{l})$ foraminiferal tests are well preserved, allowing for the acquisition of reliable geochemical data.

(Lin et al., 1997; Tedesco et al., 2007; Mohtadi et al., 2009; Jonkers and Kučera, 2015). At Site 849, seasonal temperature variability is presently $\sim 0.4^{\circ} \mathrm{C}$ (i.e., SST of $\sim 24^{\circ} \mathrm{C}$ during summer (June) versus $\sim 23.6^{\circ} \mathrm{C}$ during winter (January)). The same seasonal amplitude $\left(\sim 0.4^{\circ} \mathrm{C}\right)$ prevails at $20 \mathrm{~m}$ water depth (Locarnini et al., 2013), i.e., the assumed mean depth habitat of the investigated species G. ruber (Wang, 2000; see also Sect. 3). Further, we suggest that seasonality decreases as water depth increases; therefore it should be $<0.4^{\circ} \mathrm{C}$ at the calcification depth of G. crassaformis. Thus, because of the low seasonal temperature variability, it is rea- sonable to assume that all geochemical data derived from Site 849 (Figs. 5-8) reflect mean annual conditions.

\subsubsection{Stable isotope data}

The $\delta^{18} \mathrm{O}$ record of $G$. crassaformis varies between 0.91 and $2.79 \%$ throughout the study interval $(\sim 2.75-2.4 \mathrm{Ma})$ (Fig. 5b). The lowest values correspond to interglacials and the highest values are associated with glacials. With a mean value of $2.01 \%$ o, $\delta^{18} \mathrm{O}$ values of $G$. crassaformis (this study) are $2.78 \%$ higher on average than those of G. ruber (Jakob et 

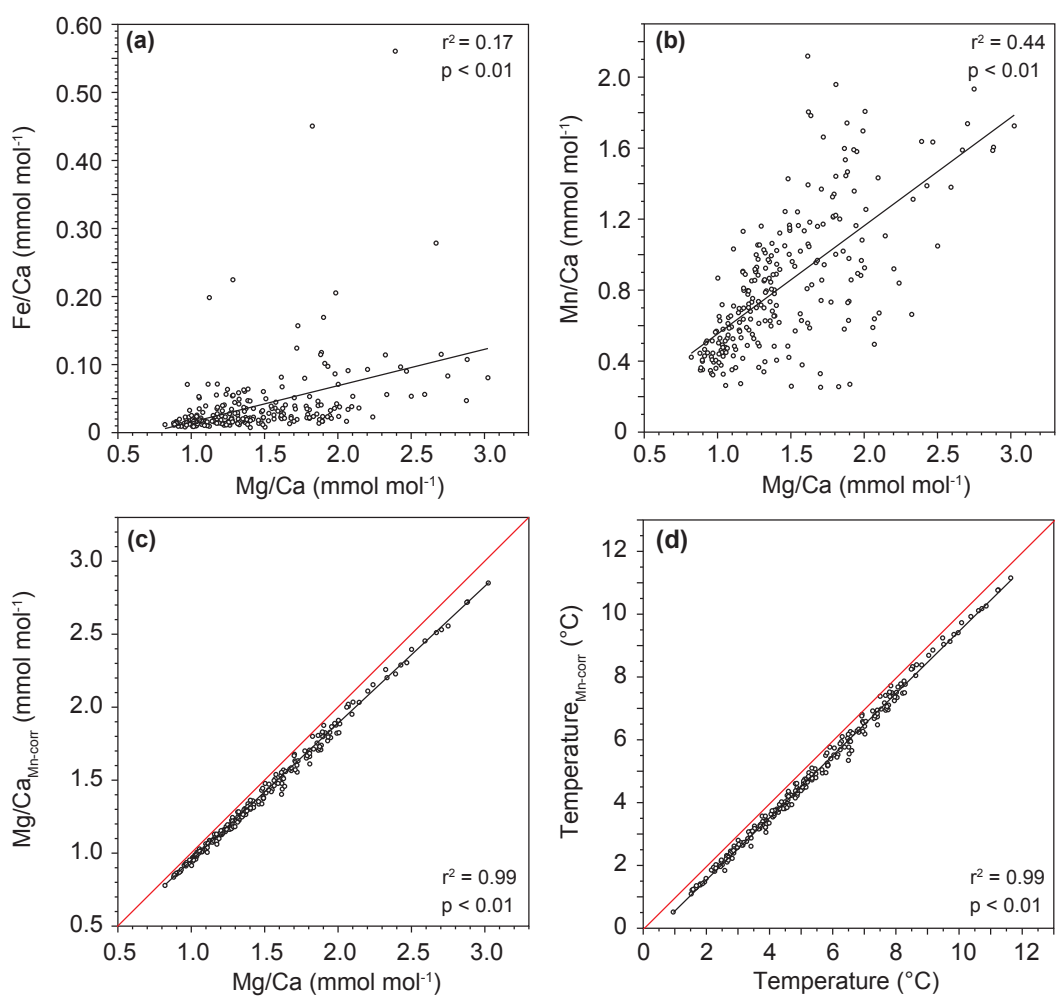

Figure 4. Evaluation of the potential contamination of $\mathrm{Mg} / \mathrm{Ca}$ ratios in G. crassaformis. (a) Scatter plot of measured $\mathrm{Mg} / \mathrm{Ca}$ and Fe / Ca ratios. (b) Scatter plot of measured $\mathrm{Mg} / \mathrm{Ca}$ and $\mathrm{Mn} / \mathrm{Ca}$ ratios. (c) Scatter plot of measured $\mathrm{Mg} / \mathrm{Ca}$ and $\mathrm{Mg} / \mathrm{Ca}$ ratios corrected for $\mathrm{Mn}$ bearing overgrowths (using the assumption of an unrealistically high $\mathrm{Mg} / \mathrm{Mn}$ ratio of 1) in comparison to uncontaminated samples (red line). (d) Scatter plot of temperatures calculated from measured $\mathrm{Mg} / \mathrm{Ca}$ and $\mathrm{Mg} / \mathrm{Ca}$ ratios corrected for Mn-bearing overgrowths (using the assumption of an unrealistically high $\mathrm{Mg} / \mathrm{Mn}$ ratio of 1) in comparison to uncontaminated samples (red line) (see Sect. 5.2 for details).

al., 2017), indicating cooler and/or more saline waters at the calcification depth of G. crassaformis (bottom of the thermocline) compared to that of G. ruber (surface waters) (Fig. 1c; see Sect. 3 for details). In theory, a deeper calcification depth of G. crassaformis than of G. ruber should result in a lower $\delta^{13} \mathrm{C}$ signature in G. crassaformis tests than in those from $G$. ruber, as the amount of organic matter remineralization and the associated release of light ${ }^{12} \mathrm{C}$ into the surrounding water typically increases with water depth (Deuser and Hunt, 1969; Kroopnick, 1985). Indeed, $\sim 1.86 \%$ ower $\delta^{13} \mathrm{C}$ values were recorded for G. crassaformis (mean: $0.46 \%$ ) than for G. ruber (mean: 2.32\%o; Jakob et al., 2016; this study) (Fig. 5c). In general, $\delta^{13} \mathrm{C}$ values of $G$. ruber and $G$. crassaformis fluctuate between minima of 1.36 and $0 \%$ during glacials and maxima of 2.97 and $0.97 \%$ o during interglacials, respectively (Jakob et al., 2016; this study) (Fig. 5c). It has been shown in a former study that the glacial-interglacial foraminiferal $\delta^{13} \mathrm{C}$ pattern at Site 849 during the iNHG is strongly controlled by the amount of primary productivity in the Southern Ocean, which is highest during interglacials (high $\delta^{13} \mathrm{C}$ ) and lowest during glacials (low $\delta^{13} \mathrm{C}$ ) (Jakob et al., 2016).

\subsubsection{Mg/Ca-based temperature data}

$\mathrm{Mg} / \mathrm{Ca}$ values of G. crassaformis vary between 0.82 and $3.02 \mathrm{mmol} \mathrm{mol}^{-1}$ (this study), and are $1.43 \mathrm{mmol} \mathrm{mol}^{-1}$ lower on average than $\mathrm{Mg} / \mathrm{Ca}$ ratios of $G$. ruber from the same site and time interval (Jakob et al., 2017) (Fig. 5d). Temperatures reconstructed from G. crassaformis $\mathrm{Mg} / \mathrm{Ca}$ values cover a range from 1.0 to $11.6^{\circ} \mathrm{C}$. Thus, subthermocline temperatures at Site 849 derived from G. crassaformis are $19^{\circ} \mathrm{C}$ lower on average than SSTs as reflected by G. ruber ( $\sim 22-27^{\circ} \mathrm{C}$; Jakob et al., 2017) (Fig. 5d). To bring the G. crassaformis-based temperatures of this study into a broader temporal and geographical context, we compare this record to a number of other relevant datasets:

i. The temperature range reconstructed based on G. crassaformis at Site 849 is close to temperatures inferred for the same species and time interval at Deep Sea Drilling Project (DSDP) Site 214 in the tropical eastern Indian Ocean $\left(\sim 8-10^{\circ} \mathrm{C}\right.$; Karas et al., 2009) (Figs. 1a, 6). Available $\mathrm{Mg} / \mathrm{Ca}$-based thermocline temperature records from the eastern Pacific for the $\sim 2.75-2.4 \mathrm{Ma}$ interval capture ranges of $\sim 17-22.5^{\circ} \mathrm{C}$ (ODP Site 1241, G. tumida-based; Steph et al., 2006a), 18- 


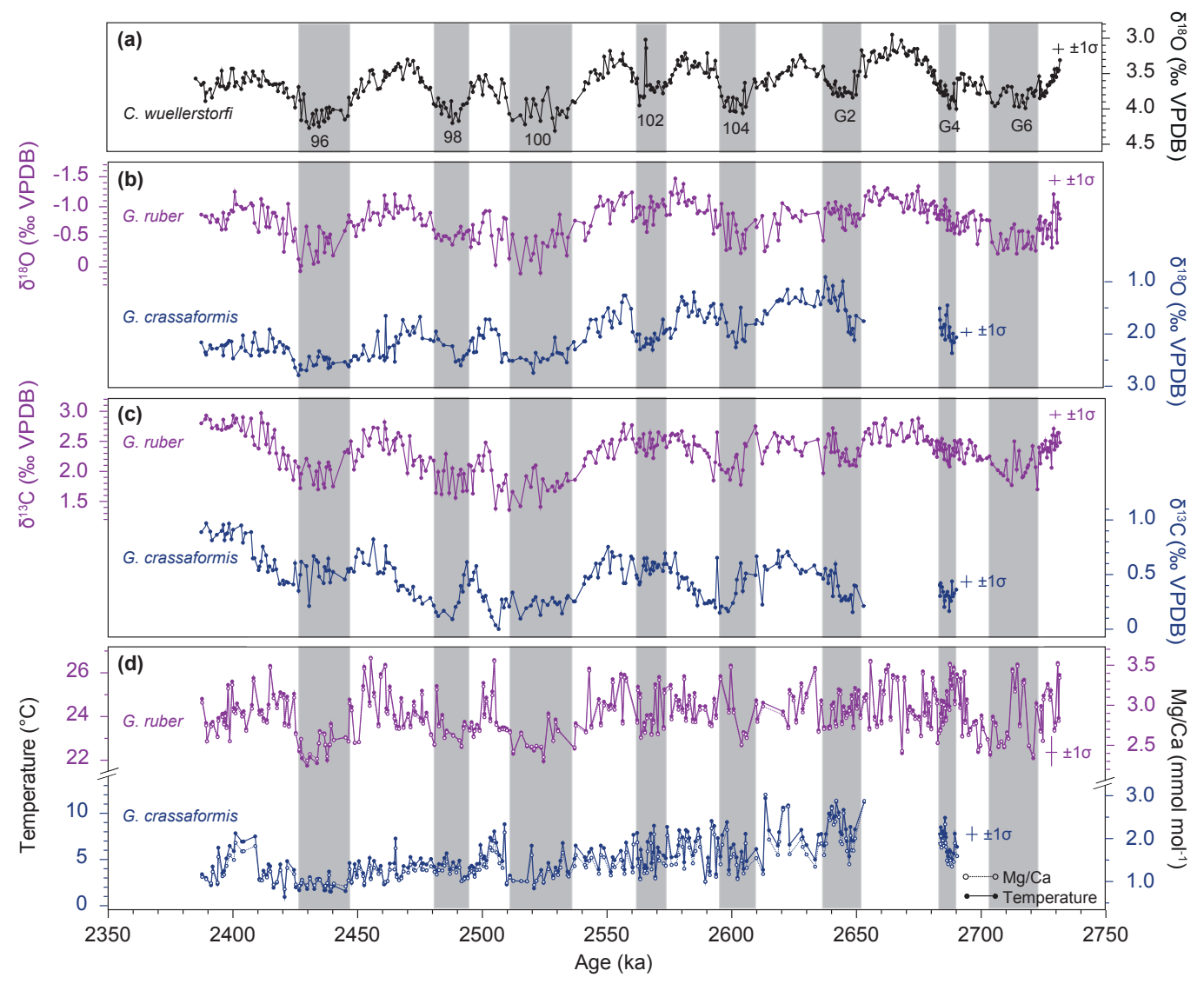

Figure 5. Planktic foraminiferal proxy records from ODP Site 849 for MIS G7-95 ( 2.75-2.4 Ma). (a) Benthic foraminiferal (C. wuellerstorfi) $\delta^{18} \mathrm{O}$ stratigraphy (Jakob et al., 2017). (b) $\delta^{18} \mathrm{O}$ data of G. ruber (purple; Jakob et al., 2017) and G. crassaformis (blue; this study). (c) $\delta^{13} \mathrm{C}$ data of G. ruber (purple; Jakob et al., 2016, this study) and G. crassaformis (blue; Jakob et al., 2016, this study). (d) Mg / Ca (dashed line, open dots) and temperature (solid line, filled dotes) data of G. ruber (purple; Jakob et al., 2017) and G. crassaformis (blue; this study). Gaps in the G. crassaformis dataset for 2.68-2.65 Ma (MIS G3) and 2.73-2.69 Ma (MIS G7-G5) are due to the lack of G. crassaformis specimens in the investigated size fraction $(315-400 \mu \mathrm{m})$. Horizontal and vertical bars indicate the $1 \sigma$ standard deviation associated with the age model and the individual proxy records, respectively. Grey bars highlight glacial periods.

$21^{\circ} \mathrm{C}$ (Site 1241, N. dutertrei-based; Groeneveld et al., 2014) and $\sim 15.5-17.5^{\circ} \mathrm{C}$ (Site 849, G. tumida-based; Ford et al., 2012) (Figs. 1a, b and 6). In comparison to thermocline temperature records from Site 1241 (Steph et al., 2006a; Groeneveld et al., 2014) our new G. crassaformis-based temperatures appear to be relatively low. However, this discrepancy can likely be explained by different calcification depths of the investigated species (which means that different temperatures are reflected; Cléroux et al., 2013) and differences in the oceanographic setting of the investigated sites (i.e., Site 849 in the "cold tongue" versus Site 1241 in the "warm pool" with, for example, a modern-day SST difference of $\sim 3{ }^{\circ} \mathrm{C}$; Locarnini et al., 2013; see also Sect. 5.4.1). The record from Site 849 by Ford et al. (2012) is of low temporal resolution (with only six datapoints across our study interval) such that peak (both glacial and interglacial) temperatures are probably not captured. There- fore, a comparison to this record is not robust enough to warrant further discussion.

ii. The EEP upwelling system is mainly fed by waters derived from the Southern Ocean (e.g., Tsuchiya et al., 1989). However, relatively warm SSTs in the Southern Ocean during our study interval $\left(\sim 10.5-17^{\circ} \mathrm{C}\right.$ at ODP Site 1090, Martínez-Garcia et al., 2010; Fig. 1a, - a site accepted as the best end-member of Southern Ocean waters, Billups et al., 2002; Pusz et al., 2011) are difficult to reconcile with substantially lower temperatures recorded in thermocline waters at EEP Site 849 $\left(\sim 1-11.6^{\circ} \mathrm{C}\right.$; this study) and Indian Ocean Site 214 ( 8-10 ${ }^{\circ} \mathrm{C}$; Karas et al., 2009). Together, these datasets imply strong cooling of Southern Ocean surface waters either when being downwelled and transported to the lower latitudes and/or through mixing with cold 

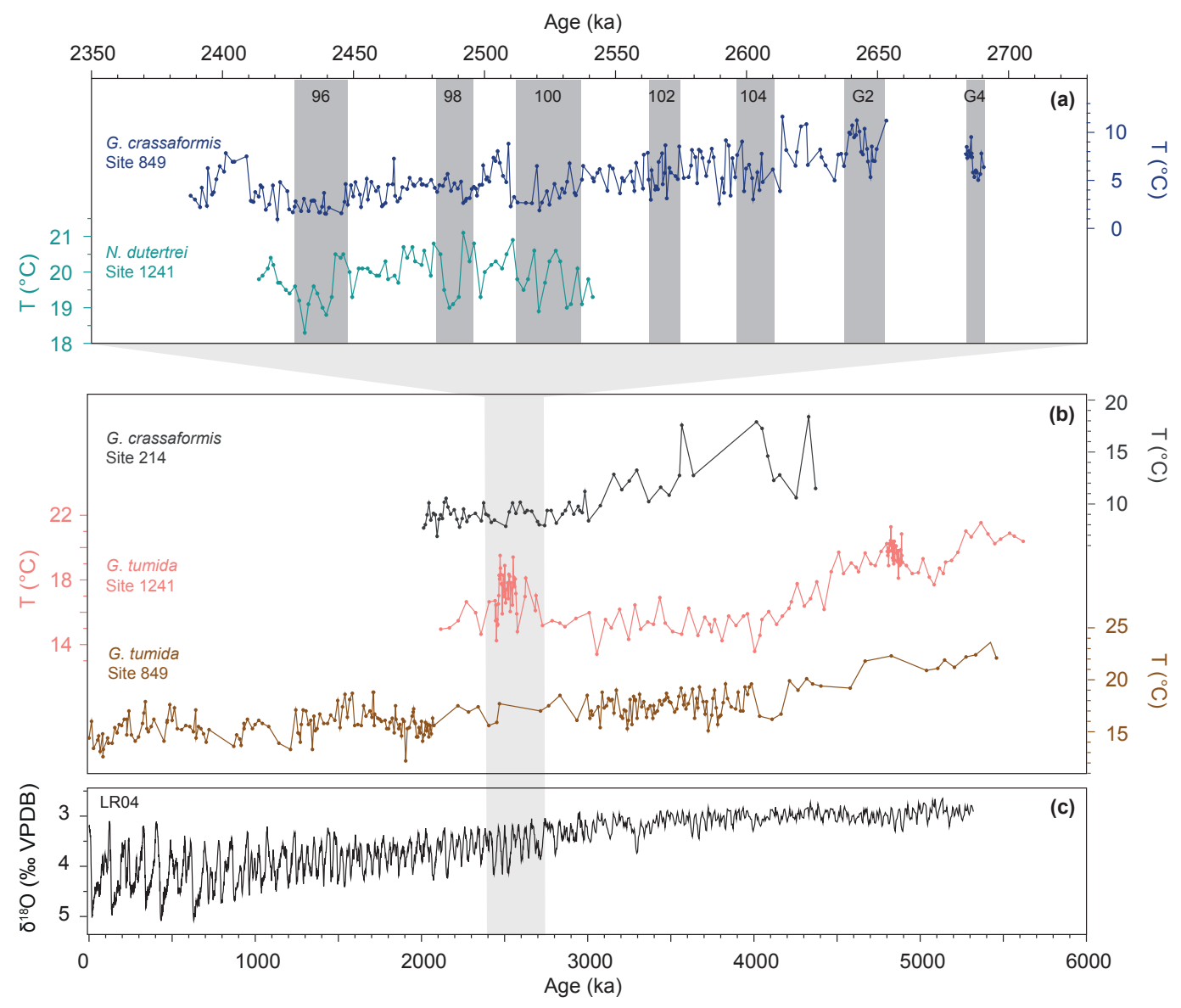

Figure 6. Comparison of selected thermocline-temperature records from the tropical Pacific for the past $\sim 6 \mathrm{Myr}$ (bottom) and the $\sim 2.75-$ 2.4 Ma interval (top). (a) High-resolution Mg / Ca-based temperature records of thermocline-dwelling species from Site 849 (blue; this study) and Site 1241 (cyan; Groeneveld et al., 2014). (b) Low-resolution Mg / Ca-based temperature records of thermocline-dwelling species from Site 214 (grey; Karas et al., 2009), Site 1241 (pink; Steph et al., 2006a) and Site 849 (brown; Ford et al., 2012). (c) Benthic oxygen isotope record (LR04 stack; Lisiecki and Raymo, 2005). Light grey shading in (b) and (c) marks the investigated time period of this study. Grey bars in (a) highlight glacial periods.

(presently $\sim 0^{\circ} \mathrm{C}$; Craig and Gordon, 1965) Antarctic Bottom Waters.

iii. Thermocline temperatures of the Last Glacial Maximum are expected to be substantially colder than those of the Plio-Pleistocene transition (Ford et al., 2012). However, in comparison to tropical east Pacific thermocline temperatures of the Last Glacial Maximum (on average $\sim 14-16^{\circ} \mathrm{C}$ ), which are derived from $\mathrm{Mg} / \mathrm{Ca}$ data of G. tumida from Site 849 (Ford et al., 2015) and N. dutertrei from Sites 08JC and 17JC (Hertzberg et al., 2016) (Fig. 1a), deep-thermocline temperatures of G. crassaformis at Site 849 from the $\sim 2.75$ to $2.4 \mathrm{Ma}$ interval appear to be too low. We suggest that different calcification depths of the investigated species may explain this discrepancy (Cléroux et al., 2013).

iv. Finally, we notice that modern bottom-water temperatures at our study site of $\sim 1.5^{\circ} \mathrm{C}$ (Locarnini et al.,
2013) overlap the deep-thermocline temperature range as reconstructed from G. crassaformis-based $\mathrm{Mg} / \mathrm{Ca}$ data. However, very low G. crassaformis-based temperatures of $\sim 1{ }^{\circ} \mathrm{C}$ are derived from a single data point, while temperatures typically higher than $2-3^{\circ} \mathrm{C}$, even during prominent iNHG glacials, can be better reconciled with present-day bottom-water temperatures.

\subsection{Thermocline development in the eastern equatorial Pacific}

\subsubsection{Geochemical evidence}

Variations in the vertical temperature gradient within the upper water column allow for the effective monitoring of shifts in the thermocline depth, with a small temperature difference between surface and thermocline waters indicating a deep thermocline and vice versa (e.g., Steph et al., 2009; Nürnberg 

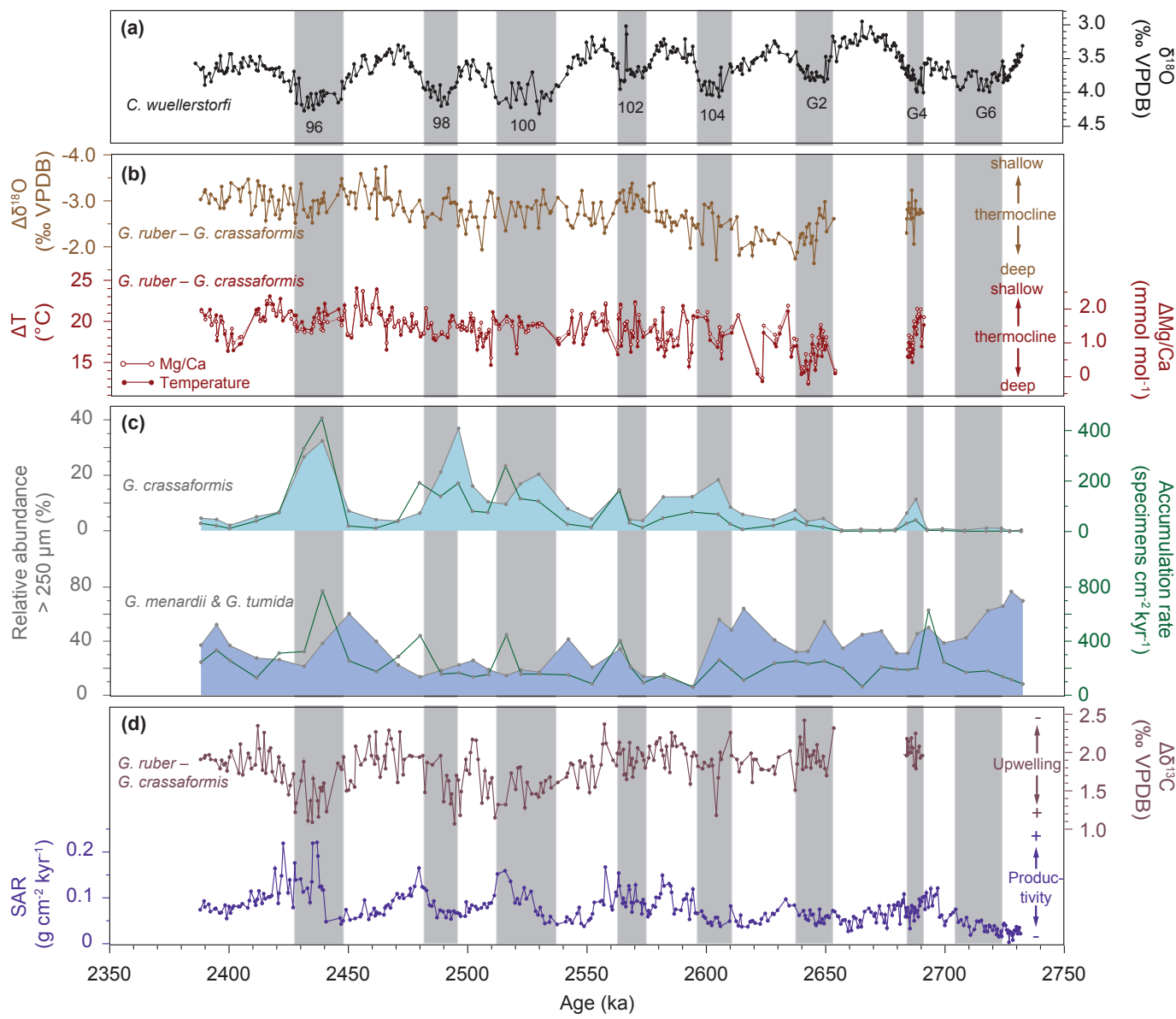

Figure 7. Compilation of planktic foraminiferal, faunal and sedimentary proxy records from ODP Site 849 for MIS G7-95 ( 2.75-2.4 Ma). (a) Benthic foraminiferal (C. wuellerstorfi) $\delta^{18} \mathrm{O}$ stratigraphy (Jakob et al., 2017). (b) $\delta^{18} \mathrm{O}$ (brown; this study) and $\mathrm{Mg} / \mathrm{Ca}$ (red dashed line with open dots; this study) and temperature (red; this study) gradients between the surface-dwelling species G. ruber and the thermoclinedwelling species $G$. crassaformis as a proxy for relative thermocline depth. (c) Relative abundances of G. crassaformis (light blue; this study) and G. menardii and G. tumida (dark blue; this study) in addition to their mass accumulation rates (green; this study). (d) $\delta^{13} \mathrm{C}$ gradient between G. ruber and G. crassaformis as an indicator for upwelling strength (purple; Jakob et al., 2016, this study) in addition to sand accumulation rates (SAR) as an indicator for primary productivity (Jakob et al., 2016, this study). Gaps in the $\delta^{18} \mathrm{O}, \delta^{13} \mathrm{C}$ and $\mathrm{Mg} / \mathrm{Ca}$ gradients for 2.68-2.65 Ma (MIS G3) and 2.73-2.69 Ma (MIS G7-G5) are due to a lack of G. crassaformis specimens in the investigated size fraction $(315-400 \mu \mathrm{m})$. Grey bars highlight glacial periods.

et al., 2015). Absolute values of surface to thermocline temperature gradients can be reconstructed from the $\mathrm{Mg} / \mathrm{Ca}-$ based temperature gradient derived from surface-dwelling and thermocline-dwelling foraminiferal species. In addition, the $\delta^{18} \mathrm{O}$ gradient provides information on relative changes in the surface to thermocline temperature gradient (as opposed to absolute estimates derived from the $\mathrm{Mg} / \mathrm{Ca}$ gradient). This is because salinity might also play a role in controlling the $\delta^{18} \mathrm{O}$ values of foraminifera inhabiting different depths. The effect of global ice volume (i.e., the third factor beside temperature and salinity that affect foraminiferal $\delta^{18} \mathrm{O}$; Ravelo and Hillaire-Marcel, 2007) should be identical. For gradient calculations, G. ruber is ideally suited as a surface-water recorder since it is one of the shallowest-dwelling species among modern planktic foraminifera (Bé, 1977); G. crassaformis appears to be one of the most promising recorders of the deep thermocline due to its rather constant calcification depth compared to other deep dwellers (Cléroux and LynchStieglitz, 2010). This approach (i.e., G. ruber to G. crassaformis gradient calculation) has already successfully been applied by previous studies that have investigated changes in the surface-water structure and the thermocline through time (e.g., Karas et al., 2009; Bahr et al., 2011).

The $\delta^{18} \mathrm{O}$ - and $\mathrm{Mg} / \mathrm{Ca}$-based temperature gradients between $G$. ruber and G. crassaformis at Site 849 show no glacial-interglacial cyclicity (Fig. 7b), indicating that the thermocline depth was unaffected by varying glacial versus interglacial climatic conditions. This observation is in 

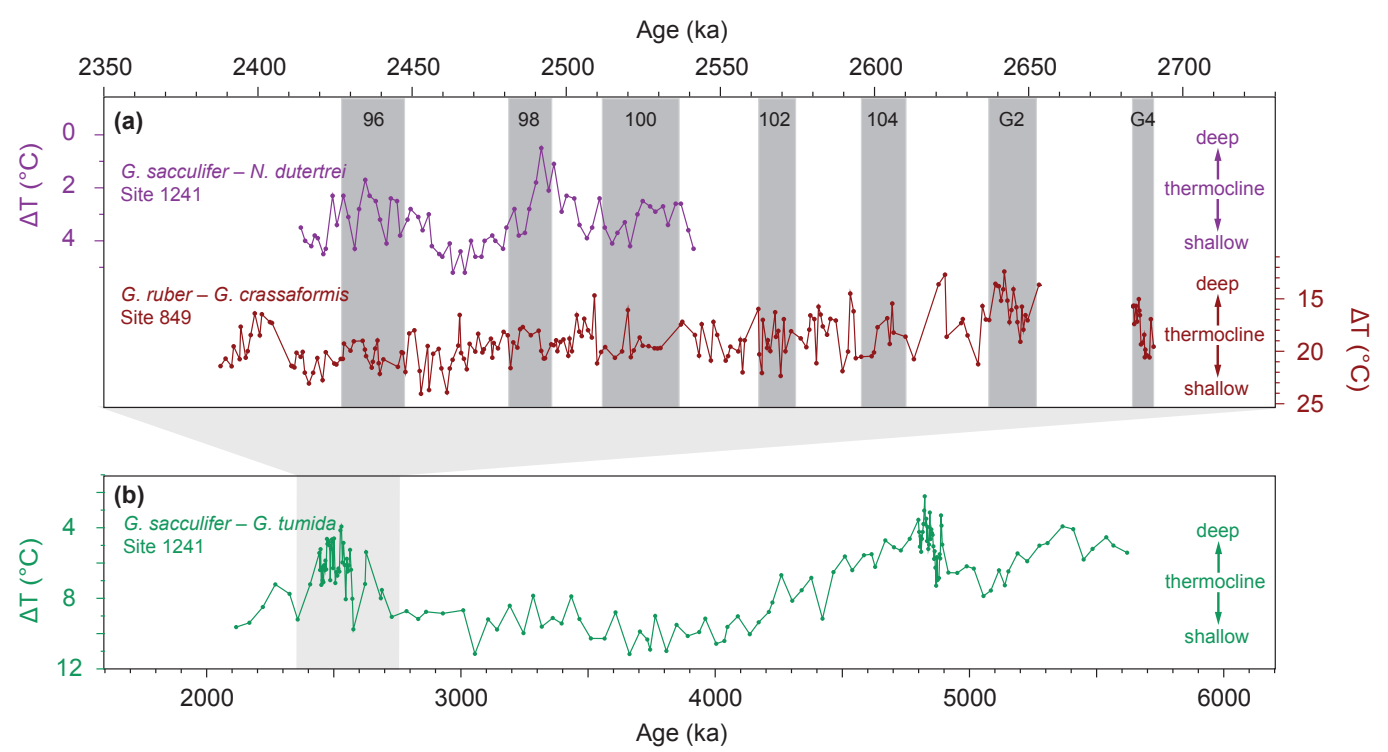

Figure 8. Comparison of selected thermocline-depth proxy records from the east Pacific for the $\sim 6-2 \mathrm{Ma}$ (bottom) and the $\sim 2.75-2.4 \mathrm{Ma}$ (top) intervals. (a) High-resolution surface to thermocline temperature gradients from Site 849 (red; this study) and Site 1241 (purple; Groeneveld et al., 2014) indicative of relative thermocline depth changes. (b) Low-resolution surface to thermocline temperature gradient from Site 1241 (green; Groeneveld et al., 2006; Steph et al., 2006a) reflecting relative thermocline depth changes. Light grey shading in (b) marks the investigated time period of this study. Grey bars in (a) highlight glacial periods.

line with previous modeling efforts (Lee and Poulsen, 2005) and proxy-based (both geochemical and faunal) studies from EEP "cold tongue" ODP Sites 846 and 849 that cover the same time interval (Bolton et al., 2010; Jakob et al., 2017). However, it contradicts geochemical data (i.e., the surface to thermocline (Globigerinoides sacculifer to N. dutertrei) $\mathrm{Mg}$ / Ca-based temperature gradient) derived from Site 1241 located in the east Pacific "warm pool", which shows glacialinterglacial variations in thermocline depth for MIS 100-96 (Groeneveld et al., 2014) (Fig. 8). Therefore, we hypothesize that thermocline depth underwent a different evolution on the glacial-interglacial timescale in regions inside (Sites 846 and 849) and outside (Site 1241) the "cold tongue". Further, water column stratification and thermocline depth at Site 1241 has been shown to be affected by glacioeustatic closures of the Central American Seaway that temporally occurred during MIS 100-96 (Groeneveld et al., 2014), perhaps due to upwelling intensification (Schneider and Schmittner, 2006). In contrast, Site 849 appears to be unaffected by such changes, as shown by sand accumulation rate based data on export production (Jakob et al., 2016). Hence, it is likely that Site 1241 reflects a more local signal as opposed to the open ocean, quasi-global signal reported at Site 849 due to its position west of the East Pacific Rise (Mix et al., 1995).

On longer timescales, the $\delta^{18} \mathrm{O}$ gradient at Site 849 decreased by $\sim 1 \%$ o from $\sim 2.64$ to $2.55 \mathrm{Ma}$ (MIS G2-101), and remained relatively constant throughout the remainder of our study interval ( 2.55-2.38 Ma; MIS 101-95) (Fig. 7b). The $\mathrm{Mg} / \mathrm{Ca}$-based temperature gradient shows the same overall pattern as the $\delta^{18} \mathrm{O}$ gradient (i.e., a $\sim 5^{\circ} \mathrm{C}$ increase from $\sim 2.64$ to $2.55 \mathrm{Ma}$, and a constant value of $\sim 20^{\circ} \mathrm{C}$ from $\sim 2.55$ to $2.38 \mathrm{Ma}$ ) (Fig. $7 \mathrm{~b}$ ). We interpret the decrease in the $\delta^{18} \mathrm{O}$ gradient and the increase in the $\mathrm{Mg} / \mathrm{Ca}$-based temperature gradient from $\sim 2.64$ to $2.55 \mathrm{Ma}$ as representing a shoaling of the thermocline. From that time onwards, constant $\delta^{18} \mathrm{O}$ and $\mathrm{Mg} / \mathrm{Ca}$-based temperature gradients suggest that the thermocline remained relatively shallow throughout the final phase of the late Pliocene/early Pleistocene iNHG until $\sim 2.38 \mathrm{Ma}$. In general, the shoaling trend of the thermocline revealed by our records agrees with the overall long-term shoaling trend of the thermocline in the EEP observed throughout the Plio-Pleistocene (Fedorov et al., 2006; Steph et al., 2006a, 2010; Dekens et al., 2007; Ford et al., 2012), although substantial thermocline shoaling is restricted to the $\sim 2.64-2.55$ Ma period rather than occurring continuously throughout the entire investigated time interval (Fig. 8). However, our data do not confirm previous datasets indicating that most prominent thermocline shoaling occurred prior to $\sim 3.5 \mathrm{Ma}$ (Wara et al., 2005; Steph et al., 2006a, 2010; Ford et al., 2012). Geochemical data from Site 1241 even reveal a transient thermocline deepening for the $\sim 2.7-2.5 \mathrm{Ma}$ interval (Steph et al., 2006a) (Fig. 8), which also cannot be confirmed by our records from Site 849 and supports the fact that Site 1241 might reflect a more local signal (see above). Other records used to infer thermocline evolution in the east Pacific for this interval lack the required temporal resolution ( 10-30 kyr, Wara et al., 2005; Dekens et al., 2007; and Ford et al., 2012, versus $\sim 0.75-3 \mathrm{kyr}$, Steph et al., 2006a 
and this study) to resolve transient thermocline changes as observed at Site 1241, if they exist.

\subsubsection{Faunal and sedimentological evidence}

Based on our data, the overall abundances of the deepthermocline-dwelling species G. crassaformis at Site 849 were relatively low when the thermocline was relatively deep (i.e., prior to $\sim 2.55 \mathrm{Ma}$ as indicated by the $\delta^{18} \mathrm{O}$ and $\mathrm{Mg} / \mathrm{Ca}$-based temperature gradients) (Fig. 7c). More specifically, G. crassaformis was only present in substantially reduced numbers or was even completely absent between $\sim 2.73$ and $2.64 \mathrm{Ma}$ (MIS G7-G2; with the exception of MIS G4, 2.69-2.68 Ma). Since $\sim 2.64 \mathrm{Ma}$, i.e., when the thermocline started to shoal, relative G. crassaformis abundances increased markedly from $<5$ to $\sim 10-35 \%$; consequently, representatives of this taxon are continuously present throughout the remainder of the study interval. The increase of G. crassaformis abundances occurs at the expense of the intermediate-thermocline-dwelling species $G$. menardii and G. tumida, which decline from $\sim 30$ to $75 \%$ to only $\sim 5$ to $65 \%$ (Fig. 7c). This observation suggests that prior to the final phase of the late Pliocene/early Pleistocene iNHG, when the thermocline was relatively deep, the living conditions for the deep-thermocline-dwelling species G. crassaformis were unfavorable. At the same time, low $G$. crassaformis abundances allowed intermediate-thermoclinedwelling species (such as G. menardii and G. tumida) to dominate the planktic foraminiferal assemblages. However, we note that the thermocline depth is most probably not the sole factor regulating $G$. crassaformis abundances. This is because this species only reaches low percentages within modern planktic foraminiferal assemblages in the EEP (typically $<1 \%$ in core-top samples; Prell, 1985), although the present-day thermocline is relatively shallow.

In general, G. crassaformis reaches highest abundances in oxygen-depleted waters (Jones, 1967; Kemle von Mücke and Hemleben, 1999), while other environmental factors including temperature, salinity or nutrient availability are markedly less important (Cléroux et al., 2013). The oxygen content of deep waters (and accordingly the abundance of $G$. crassaformis) is typically closely coupled to surface-water productivity (with a lower oxygen level and higher G. crassaformis abundances in deeper waters when surface-water productivity is high) (Wilson et al., 2017). Therefore, we hypothesize that primary productivity at Site 849 prior to $\sim 2.64 \mathrm{Ma}$ (MIS G2) was relatively low (with the exception of MIS G4). Low primary productivity led to a reduction of organic matter remineralization and related oxygen consumption in deeper waters. An elevated oxygen content in deeper waters implies, in turn, low G. crassaformis abundances. Such a scenario is supported by the sand accumulation rate based primary productivity record from Site 849 (Jakob et al., 2016; this study), which clearly indicates low productivity rates prior to $\sim 2.64 \mathrm{Ma}$ when the thermocline was relatively deep compared to after $\sim 2.64 \mathrm{Ma}$ when the thermocline became shallow (Fig. 7b, d).

As outlined above, on longer timescales primary productivity at Site 849 appears to be coupled to variations in the thermocline depth. The observed long-term trend in primary productivity is overprinted by a clear glacialinterglacial cyclicity, particularly during the final phase of iNHG (MIS 100-96); however, the position of the thermocline remained constant along the obliquity (i.e., $41 \mathrm{kyr}$ ) band (Fig. 7b, d). Notably, the accumulation rates of G. crassaformis, G. menardii and G. tumida perfectly capture the pattern derived by the sand accumulation rate based productivity record (Fig. 7c, d). This suggests that the abundances of deep- and intermediate-thermocline-dwelling foraminiferal species are coupled to the strength of the biological pump and can be used as a tracer for primary productivity at Site 849 .

The relatively high $\delta^{13} \mathrm{C}$ gradient for MIS G4-G2, as it emerges from our data (Fig. 7d), confirms the interpretation of Jakob et al. (2016) for MIS G1-95, which was that low-amplitude productivity changes prior to MIS 100 were mainly driven by the nutrient content within the upwelled water mass as long as the thermocline was relatively deep (as reflected by a low thermocline to surface temperature gradient prior to $\sim 2.55 \mathrm{Ma}$, MIS 101; Fig. $7 \mathrm{~b}, \mathrm{~d}$ ). Highamplitude productivity changes resulting from upwelling intensification played an important role from MIS 100 onward (Jakob et al., 2016). At the same time, the thermocline became relatively shallow (as reflected by the large thermocline to surface temperature gradient since $\sim 2.55 \mathrm{Ma}$ (MIS 101) at Site 849; Fig. 7b, d). This is unlikely to be a coincidence, but rather suggests that the thermocline depth reached a critical threshold at that time. Prior to this, relatively warm and nutrient-poor waters from above the thermocline upwelled at EEP Site 849. Consequently, primary productivity rates were low. However, when the thermocline became shallow enough, trade winds could deliver cooler, nutrient-enriched waters from below the thermocline to the surface, which allowed primary productivity to increase. This scenario is supported by the observation that lower SSTs have prevailed at Site 849 during glacials since MIS 100 (Jakob et al., 2017) (Fig. 5d). Moreover, temporal closures of the Central American Seaway might have additionally promoted generally increasing upwelling and therefore primary productivity rates since MIS 100 (Schneider and Schmittner, 2006; Groeneveld et al., 2014).

Our findings imply a marked effect of long-term thermocline state change on primary productivity at the studied site. In particular, when thermocline shoaling reached a critical threshold, primary productivity increased, thereby removing $\mathrm{CO}_{2}$ from the surface ocean. Thermocline shoaling appears to be a consistent feature in the EEP throughout the Plio-Pleistocene (although the timing and magnitude varies between different studies which may be related to the different approaches used for thermocline reconstruction or different localities and local oceanography). Considering 
that the entire EEP substantially contributes to global biological production in the present-day oceans (Pennington et al., 2006), the observed coupling between thermocline state change and primary productivity (if this behavior is similar across the entire EEP "cold tongue") is of major importance for the Earth's climate; it may have favored global cooling and the subsequent early development of large ice sheets in the Northern Hemisphere. At the same time, as suggested in previous studies, the formation of the "cold tongue" through thermocline shoaling might have additionally preconditioned the iNHG by reducing atmospheric heat transport from the tropics to the poles (Cane and Molnar, 2001).

\section{Conclusions}

We integrate new and previously published foraminiferalbased geochemical, faunal and sedimentological records from ODP Site $849(\sim 2.75-2.4 \mathrm{Ma}$, MIS G7-95) to reconstruct changes in the thermocline depth during the late Pliocene/early Pleistocene iNHG. Our data document a shoaling of the thermocline at Site 849 from $\sim 2.64$ to $2.55 \mathrm{Ma}$, while it remained relatively shallow until $\sim$ $2.38 \mathrm{Ma}$. This implies that major changes in thermocline depth occurred shortly before the final phase of the late Pliocene/early Pleistocene iNHG (i.e., prior to MIS 100-96). This finding, which is in line with former studies (Fedorov et al., 2006; Dekens et al., 2007), supports the hypothesis that (sub-)tropical thermocline shoaling was a precondition to allow the development of large ice sheets in the Northern Hemisphere (Cane and Molnar, 2001). At the same time, our new data contradict studies that have documented substantial shifts in thermocline depth in the EEP only prior to $\sim 3.5 \mathrm{Ma}$ (Wara et al., 2005; Steph et al., 2006a, 2010; Ford et al., 2012). Our new records also suggest low primary productivity rates during periods when the thermocline is relatively deep prior to $\sim 2.64 \mathrm{Ma}$ (MIS G2). In turn, the relatively shallow thermocline associated with low SSTs after $\sim 2.55 \mathrm{Ma}$ allowed primary productivity to increase during prominent iNHG glacials (MIS 100-96) and, perhaps, by removing $\mathrm{CO}_{2}$ from ocean-atmosphere exchange processes, to further stimulate Northern Hemisphere ice-sheet growth.

Data availability. The data associated with this paper are provided in the Supplement (Tables S1 to S4).

Supplement. The supplement related to this article is available online at: https://doi.org/10.5194/cp-14-1079-2018-supplement.

Author contributions. The project was designed by OF, KAJ and JP. KAJ and CS carried out the Mg / Ca analyses; JF and KAJ performed the stable isotope analyses. KAJ wrote the manuscript with input from all co-authors.
Competing interests. The authors declare that they have no conflict of interest.

Acknowledgements. Richard Norris provided invaluable support regarding foraminiferal taxonomy. Sven Hofmann and Silvia Rheinberger are thanked for the stable isotope and $\mathrm{Mg} / \mathrm{Ca}$ analyses, respectively. André Bahr provided support with the $\mathrm{Mg} / \mathrm{Ca}$ sample preparation. Hans-Peter Meyer and Alexander Varychev provided SEM assistance. Jani L. Biber, Verena Braun, Jakob Gänzler, Barbara Hennrich, Karsten Kähler and Tobias Syla helped with the processing of sediment samples. Comments and suggestions by the editor Luc Beaufort and two anonymous reviewers are highly appreciated. This research used samples provided by the Ocean Drilling Program, which was sponsored by the US National Science Foundation and participating countries under the management of Joint Oceanographic Institutions, Inc. Funding for this study was provided by the German Research Foundation (DFG; grant FR2544/6 to Oliver Friedrich and grant PR651/15 to Jörg Pross). Further, we acknowledge financial support from the DFG within the funding program Open Access Publishing, from the Baden-Württemberg Ministry of Science, Research and the Arts and from Ruprecht-Karls-Universität Heidelberg.

Edited by: Luc Beaufort

Reviewed by: two anonymous referees

\section{References}

Adelseck, C. G. and Anderson, T. F.: The late Pleistocene record of productivity fluctuations in the eastern equatorial Pacific Ocean, Geology, 6, 388-391, 1978.

Anand, P., Elderfield, H., and Conte, M. H.: Calibration of $\mathrm{Mg} / \mathrm{Ca}$ thermometry in planktonic foraminifera from a sediment trap time series, Paleoceanography, 18, 1050, https://doi.org/10.1029/2002PA000846, 2003.

Bahr, A., Nürnberg, D., Schönfeld, J., and Garbe-Schönberg, D.: Hydrological variability in Florida Straits during Marine Isotope Stage 5 cold events, Paleoceanography, 26, PA2214, https://doi.org/10.1029/2010PA002015, 2011.

Bailey, I., Hole, G. M., Foster, G. L., Wilson, P. A., Storey, C. D., Trueman, C. N., and Raymo, M. E.: An alternative suggestion for the Pliocene onset of major northern hemisphere glaciation based on the geochemical provenance of North Atlantic Ocean ice-rafted debris, Quaternary Sci. Rev., 75, 181-194, 2013.

Barker, S., Greaves, M., and Elderfield, H.: A study of cleaning procedures used for foraminiferal $\mathrm{Mg} / \mathrm{Ca}$ paleothermometry, Geochem. Geophy. Geosy., 4, 8407, https://doi.org/10.1029/2003GC000559, 2003.

Bartoli, G., Sarnthein, M., and Weinelt, M.: Late Pliocene millennial-scale climate variability in the northern North Atlantic prior to and after the onset of Northern Hemisphere glaciation, Paleoceanography, 21, PA4205, https://doi.org/10.1029/2005PA001185, 2006.

Bé, A. W. H.: An ecological, zoogeographic and taxonomic review of recent planktonic foraminifera, in: Oceanic micropaleontol- 
ogy, edited by: Ramsey, A. T. S., Academic Press, London, 1100, 1977.

Berger, W. H., Bonneau, M.-C., and Parker, F. L.: Foraminifera on the deep-sea floor: lysocline and dissolution rate, Oceanol. Acta, 5, 249-258, 1982.

Billups, K., Channell, J. E. T., and Zachos, J.: Late Oligocene to early Miocene geochronology and paleoceanography from the subantarctic South Atlantic, Paleoceanography, 17, 1004, https://doi.org/10.1029/2000PA000568, 2002.

Bolton, C. T., Gibbs, S. J., and Wilson, P. A.: Evolution of nutricline dynamics in the equatorial Pacific during the late Pliocene, Paleoceanography, 25, PA1207, https://doi.org/10.1029/2009PA001821, 2010.

Cane, M. A. and Molnar, P.: Closing of the Indonesian seaway as a precursor to east African aridification around 3-4 million years ago, Nature, 411, 157-162, 2001.

Cléroux, C. and Lynch-Stieglitz, J.: What caused G. truncatulinoides to calcify in shallower water during the early Holocene in the western Atlantic/Gulf of Mexico?, IOP Conf. Ser. Earth Environ. Sci., 9, 012020, https://doi.org/10.1088/17551315/9/1/012020, 2010

Cléroux, C., deMenocal, P., Arbuszewski, J., and Linsley, B.: Reconstructing the upper water column thermal structure in the Atlantic Ocean, Paleoceanography, 28, 503-516, 2013.

Craig, H. and Gordon, L. I.: Deuterium and oxygen-18 variations in the ocean and the marine atmosphere, in: Stable isotopes in oceanographic studies and paleotemperatures, edited by: Tongiorgi, E., Spoletto, Pisa, 9-130, 1965.

Dekens, P. S., Lea, D. W., Pak, D. K., and Spero, H. J.: Core top calibration of $\mathrm{Mg} / \mathrm{Ca}$ in tropical foraminifera: Refining paleotemperature estimation, Geochem. Geophy. Geosy., 3, 1-29, https://doi.org/10.1029/2001GC000200, 2002.

Dekens, P. S., Ravelo, A. C., and McCarthy, M. D.: Warm upwelling regions in the Pliocene warm period, Paleoceanography, 22, PA3211, https://doi.org/10.1029/2006PA001394, 2007.

Deuser, W. G. and Hunt, J. M.: Stable isotope ratios of dissolved inorganic carbon in the Atlantic, Deep-Sea Res., 16, 221-225, 1969.

Dittert, N., Baumann, K.-H., Bickert, T., Henrich, R., Huber, R., Kinkel, H., and Meggers, H.: Carbonate dissolution in the deepsea: Methods, quantification and paleoceanographic application, in: Use of Proxies in Paleoceanography, edited by: Fischer, G. and Wefer, G., Springer, New York, 255-284, 1999.

Elderfield, H., Vautravers, M., and Cooper, M.: The relationship between shell size and $\mathrm{Mg} / \mathrm{Ca}, \mathrm{Sr} / \mathrm{Ca}, \delta^{18} \mathrm{O}$, and $\delta^{13} \mathrm{C}$ of species of planktonic foraminifera, Geochem. Geophy. Geosy., 3, 1-13, https://doi.org/10.1029/2001GC000194, 2002.

Etourneau, J., Schneider, R., Blanz, T., and Martinez, P.: Intensification of the Walker and Hadley atmospheric circulations during the Pliocene-Pleistocene climate transition, Earth Planet. Sc. Lett., 297, 103-110, 2010.

Fairbanks, R. G., Sverdlove, M., Free, R., Wiebe, P., and Bé, W.: Vertical distribution and isotopic fractionation of living planktonic foraminifera from the Panama Basin, Nature, 298, 841844, 1982.

Faul, K. L., Ravelo, A. C., and Delaney, M. L.: Reconstructions of upwelling, productivity, and photic zone depth in the eastern equatorial Pacific Ocean using planktonic foraminiferal sta- ble isotopes and abundances, J. Foramin. Res., 30, 110-125, https://doi.org/10.2113/0300110, 2000.

Fedorov, A. V. and Philander, S. G.: Is El Nino changing?, Science, 288, 1997-2002, 2000.

Fedorov, A. V., Pacanowski, R. C., Philander, S. G., and Boccaletti, G.: The effect of salinity on the wind-driven circulation and the thermal structure of the upper ocean, J. Phys. Oceanogr., 34, 1949-1966, 2004.

Fedorov, A. V., Dekens, P. S., McCarthy, M., Ravelo, A. C., deMenocal, P. B., Barriero, M., Pacanowski, R. C., and Philander, S. G.: The Pliocene paradox (mechanisms for a permanent El Niño), Science, 312, 1485-1489, 2006.

Ford, H. L., Ravelo, A. C., and Hovan, S.: A deep Eastern Equatorial Pacific thermocline during the early Pliocene warm period, Earth Planet. Sc. Lett., 355-356, 152-161, 2012.

Ford, H. L., Ravelo, A. C., and Polissar, P. J.: Reduced El NiñoSouthern Oscillation during the Last Glacial Maximum, Science, 347, 255-258, 2015.

Friedrich, O., Schiebel, R., Wilson, P. A., Weldeab, S., Beer, S. J., Cooper, M. J., and Fiebig, J.: Influence of test size, water depth, and ecology on $\mathrm{Mg} / \mathrm{Ca}, \mathrm{Sr} / \mathrm{Ca}, \delta^{18} \mathrm{O}$ and $\delta^{13} \mathrm{C}$ in nine modern species of planktic foraminifers, Earth Planet. Sc. Lett., 319, 133-145, 2012.

Greaves, M., Caillon, N., Rebaubier, H., Bartoli, G., Bohaty, S., Cacho, I., Clarke, L. J., Cooper, M., Daunt, C., Delaney, M., deMenocal, P., Dutton, A., Eggins, S., Elderfield, H., GarbeSchoenberg, D., Goddard, E., Green, D., Groeneveld, J., Hastings, D., Hathorne, E., Kimoto, K., Klinkhammer, G., Labeyrie, L., Lea, D. W., Marchitto, T., Martinez-Boti, M. A., Mortyn, P. G., Ni, Y., Nuernberg, D., Paradis, G., Pena, L., Quinn, T., Rosenthal, Y., Russell, A., Sagawa, T., Sosdain, S., Stott, L., Tachikawa, K., Tappa, E., Thunell, R., and Wilson, P. A.: Interlaboratory comparison study of calibration standards for foraminiferal $\mathrm{Mg}$ / Ca thermometry, Geochem. Geophy. Geosy., 9, Q08010, https://doi.org/10.1029/2008GC001974, 2008.

Groeneveld, J., Steph, S., Tiedemann, R., Garbe-Schönberg, D. Nürnberg, D., and Sturm, A.: Pliocene mixed-layer oceanography for Site 1241 , using combined $\mathrm{Mg} / \mathrm{Ca}$ and $\delta^{18} \mathrm{O}$ analyses of Globigerinoides sacculifer, in: Proc. ODP, Sci. Results, 202, College Station, TX (Ocean Drilling Program), edited by: Tiedemann, R., Mix, A. C., Richter, C., and Ruddiman, W. F., https://doi.org/10.2973/odp.proc.sr.202.209.2006, 2006.

Groeneveld, J., Hathorne, E. C., Steinke, S., DeBey, H., Mackensen, A., and Tiedemann, R.: Glacial induced closure of the Panamanian Gateway during Marine Isotope Stages (MIS) 95-100 ( 2.5 Ma), Earth Planet. Sc. Lett., 404, 296-306, 2014.

Hertzberg, J. E., Schmidt, M. W., Bianchi, T. S., Smith, R. W., Shields, M. R., and Marcantonio, F.: Comparison of eastern tropical Pacific $\mathrm{TEX}_{86}$ and Globigerinoides ruber $\mathrm{Mg} / \mathrm{Ca}$ derived sea surface temperatures: Insights from the Holocene and Last Glacial Maximum, Earth Planet. Sc. Lett., 434, 320-332, 2016.

Jakob, K. A., Wilson, P. A., Bahr, A., Bolton, C. T., Pross, J., Fiebig, J., and Friedrich, O.: Plio-Pleistocene glacialinterglacial productivity changes in the eastern equatorial Pacific upwelling system, Paleoceanography, 31, 453-470, https://doi.org/10.1002/2015PA002899, 2016.

Jakob, K. A., Bolton, C. T., Wilson, P. A., Bahr, A. Pross, J., Fiebig, J., Kähler, K., and Friedrich, O.: Glacialinterglacial changes in equatorial Pacific surface-water struc- 
ture during the Plio-Pleistocene intensification of Northern Hemisphere Glaciation, Earth Planet. Sc. Lett., 463, 69-80, https://doi.org/10.1016/j.eps1.2017.01.028, 2017.

Jones, J. I.: Significance of distribution of planktonic foraminifers in the Equatorial Atlantic Undercurrent, Micropaleontology, 13, 489-501, 1967.

Jonkers, L. and Kučera, M.: Global analysis of seasonality in the shell flux of extant planktonic Foraminifera, Biogeosciences, 12, 2207-2226, https://doi.org/10.5194/bg-12-2207-2015, 2015.

Karas, C., Nürnberg, D., Gupta, A. K., Tiedemann, R., Mohan, K., and Bickert, T.: Mid-Pliocene climate change amplified by a switch in Indonesian subsurface throughflow, Nat. Geosci., 2, 434-438, 2009.

Kemle von Mücke, S. and Hemleben, C.: Foraminifera, in: South Atlantic Zooplankton, Vol. 1, edited by: Boltovskoy, D., Backhuys Publishers, Leiden, 43-74, 1999.

Koutavas, A. and Lynch-Stieglitz, J.: Glacial-interglacial dynamics of the eastern equatorial Pacific cold tongueIntertropical Convergence Zone system reconstructed from oxygen isotope records, Paleoceanography, 18, 1089, https://doi.org/10.1029/2003PA000894, 2003.

Kroopnick, P. M.: The distribution of ${ }^{13} \mathrm{C}$ of $\Sigma \mathrm{CO}_{2}$ in the world oceans, Deep-Sea Res., 32, 57-84, 1985.

Lee, S. Y. and Poulsen, C. J.: Tropical Pacific climate response to obliquity forcing in the Pleistocene, Paleoceanography, 20, PA4010, https://doi.org/10.1029/2005PA001161, 2005.

Lin, H.-L., Peterson, L. C., Overpeck, J. T., Trumbore, S. E., and Murray, D. W.: Late Quaternary climate change from $\delta^{18} \mathrm{O}$ records of multiple species of planktonic foraminifera: Highresolution records from the Anoxic Cariaco Basin, Venezuela, Paleoceanography, 12, 415-427, 1997.

Lisiecki, L. E. and Raymo, M. E.: A Pliocene-Pleistocene stack of 57 globally distributed benthic $\delta^{18} \mathrm{O}$ records, Paleoceanography, 20, PA1003, https://doi.org/10.1029/2004PA001071, 2005.

Locarnini, R. A., Mishonov, A. V., Antonov, J. I., Boyer, T. P., Garcia, H. E., Baranova, O. K., Zweng, M. M., Paver, C. R., Reagan, J. R., Johnson, D. R., Hamilton, M., and Seidov, D.: World Ocean Atlas 2013, Volume 1, Temperature, in: NOAA Atlas NESDIS 73, edited by: Levitus, S. and Mishonov, A., U. S. Government Printing Office, Washington, D. C., 40 pp., 2013.

Ma, H., Wu, L., and Li, Z.: Impact of freshening over the Southern Ocean on ENSO, Atmos. Sci. Lett., 14, 28-33, https://doi.org/10.1002/as12.410, 2013.

Martínez-Garcia, A., Rosell-Melé, A., McClymont, E. L., Gersonde, R., and Haug, G. H.: Subpolar link to the emergence of the modern equatorial Pacific cold tongue, Science, 328, 15501553, 2010.

Mayer, L. A., Pisias, N. G., Janecek, T. R., Baldauf, J. G., Bloomer, S. F., Dadey, K. A., Emeis, K.-C., Farrell J., Flores, J. A., Galimov, E. M., Hagelberg, T. K., Holler, P., Hovan, S. A., Iwai, M., Kemp, A. E. S., Kim, D. C., Klinkhammer, G., Leinen, M., Levi, S., Levitan, M. A., Lyle, M. W., MacKillop, A. K., Meynadier, L. M., Mix, A. C., Moore, T. C., Raffi, I., Ravelo, C., Schneider, D., Shackleton, N. J., Valet, J.-P., and Vincent, E.: Eastern Equatorial Pacific, Proc. ODP, Init. Repts., 138, College Station, TX, Ocean Drilling Program, 1992.

Mix, A. C., Pisias, N. G., Rugh, W., Wilson, J., Morey, A., and Hagelberg, T. K.: Benthic foraminifer stable isotope record from Site 849 (0-5 Ma): local and global climate changes, in: Proc.
ODP, Sci. Results, 138, College Station, TX (Ocean Drilling Program), edited by: Pisias, N. G., Mayer, L. A., Janecek, T. R., Palmer-Julson, A., and van Adel, T. H., 371-412, 1995.

Mohtadi, M., Steinke, S., Groeneveld, J., Fink, H. G., Rixen, T., Hebbeln, D., Donner, B., and Herunadi, B.: Lowlatitude control on seasonal and interannual changes in planktonic foraminiferal flux and shell geochemistry off south Java: A sediment trap study, Paleoceanography, 24, PA1201, https://doi.org/10.1029/2008PA001636, 2009.

Mudelsee, M. and Raymo, M. E.: Slow dynamics of the Northern Hemisphere Glaciation, Paleoceanography, 20, PA4022, https://doi.org/10.1029/2005PA001153, 2005.

Naafs, B. D. A., Hefter, J., and Stein, R.: Millennial-scale ice rafting events and Hudson Strait Heinrich(-like) Events during the late Pliocene and Pleistocene: a review, Quaternary Sci. Rev., 80, 1$28,2013$.

Niebler, H.-S., Hubberten, H.-W., and Gersonde, R.: Oxygen isotope values of planktic foraminifera: A tool for the reconstruction of surface water stratification, in: Use of Proxies in Paleoceanography, edited by: Fischer, G. and Wefer, G., Springer, New York, 165-189, 1999.

Nürnberg, D., Böschen, T., Doering, K., Mollier-Vogel, E., Raddatz, J., and Schneider, R.: Sea surface and subsurface circulation dynamics off equatorial Peru during the last $\sim 17 \mathrm{kyr}$, Paleoceanography, 30, 984-999, https://doi.org/10.1002/2014pa002706, 2015.

Pena, L. D., Calvo, E., Cacho, I., Eggins, S., and Pelejero, C.: Identification and removal of $\mathrm{Mn}-\mathrm{Mg}$-rich contaminant phases on foraminiferal tests: Implications for $\mathrm{Mg} / \mathrm{Ca}$ past temperature reconstructions, Geochem. Geophy. Geosy., 6, Q09P02, https://doi.org/10.1029/2005GC000930, 2005.

Pennington, J. T., Mahoney, K. L., Kuwahara, V. S., Kolber, D. D., Calienes, R., and Chavez, F. P.: Primary production in the eastern tropical Pacific: A review, Prog. Oceanogr., 69, 285-317, 2006.

Prell, W. L.: The stability of low-latitude sea-surface temperatures: an evaluation of the CLIMAP reconstruction with emphasis on the positive SST anomalies. Rep. TR 025, U.S. Dep. Energy, Washington, 60 pp., 1985.

Pusz, A. E., Thunell, R. C., and Miller, K. G.: Deep water temperature, carbonate ion, and ice volume changes across the EoceneOligocene climate transition, Paleoceanography, 26, PA2205, https://doi.org/10.1029/2010PA001950, 2011.

Ravelo, A. C. and Hillaire-Marcel, C.: The use of oxygen and carbon isotopes of foraminifera in Paleoceanography, in: Proxies in Late Cenozoic Paleoceanography, edited by: Hillaire-Marcel, C. and De Vernal, A., Elsevier, Amsterdam, Oxford, 735-764, 2007.

Regenberg, M., Steph, S., Nürnberg, D., Tiedemann, R., and GarbeSchönberg, D.: Calibrating Mg / Ca ratios of multiple planktonic foraminiferal species with $\delta^{18} \mathrm{O}$-calcification temperatures: $\mathrm{Pa}-$ leothermometry for the upper water column, Earth Planet. Sc. Lett., 278, 324-336, 2009.

Schlitzer, R.: Export production in the equatorial and north $\mathrm{Pa}-$ cific derived from dissolved oxygen, nutrient and carbon data, J. Oceanogr., 60, 53-62, 2004.

Schneider, B. and Schmittner, A.: Simulating the impact of the Panamanian seaway closure on ocean circulation, marine productivity and nutrient cycling, Earth Planet. Sc. Lett., 246, 367-380, 2006. 
Sexton, P. F. and Norris, R. D.: Dispersal and biogeography of marine plankton: Long-distance dispersal of the foraminifer Truncorotalia truncatulinoides, Geology, 36, 899902, https://doi.org/10.1130/G25232A.1, 2008.

Shackleton, N. J., Backman, J., Zimmerman, H., Kent, D. V., Hall, M., Roberts, D., Schnitker, D., Baldauf, J., Desprairies, A., and Homrighausen, R.: Oxygen isotope calibration of the onset of ice-rafting and history of glaciation in the North Atlantic region, Nature, 307, 620-623, 1984.

Spero, H. J., Mielke, K. M., Kalve, E. M., Lea, D. W., and Pak, D. K.: Multispecies approach to reconstructing eastern equatorial Pacific thermocline hydrography during the past $360 \mathrm{kyr}$, Paleoceanography, 18, 1022, https://doi.org/10.1029/2002PA000814, 2003.

Steph, S., Tiedemann, R., Groeneveld, J., Sturm, A., and Nürnberg, D.: Pliocene changes in tropical east Pacific upper ocean stratification: Response to tropical gateways?, Proc. ODP, Sci. Results, 202, College Station, TX (Ocean Drilling Program), edited by: Tiedemann, R., Mix, A. C., Richter, C., and Ruddiman, W. F., https://doi.org/10.2973/odp.proc.sr.202.211.2006, 2006a.

Steph, S., Tiedemann, R., Prange, M., Groeneveld, J., Nürnberg, D., Reuning, L., Schulz, M., and Haug, G. H.: Changes in Caribbean surface hydrography during the Pliocene shoaling of the Central American Seaway, Paleoceanography, 21, PA4221, https://doi.org/10.1029/2004PA001092, 2006b.

Steph, S., Regenberg, M., Tiedemann, R., Mulitza, S., and Nürnberg, D.: Stable isotopes of planktonic foraminifera from tropical Atlantic/Caribbean core-tops: Implications for reconstructing upper ocean stratification, Mar. Micropaleontol., 71, 1-19, https://doi.org/10.1016/j.marmicro.2008.12.004, 2009.

Steph, S., Tiedemann, R., Prange, M., Groeneveld, J., Schulz, M., Timmermann, A., Nürnberg, D., Rühlemann, C., Saukel, C., and Haug, G. H.: Early Pliocene increase in thermohaline overturning: A precondition for the development of the modern equatorial Pacific cold tongue, Paleoceanography, 25, PA2202, https://doi.org/10.1029/2008PA001645, 2010.

Takahashi, T., Sutherland, S. C., Wanninkhof, R., Sweeney, C., Feely, R. A., Chipman, D. W., Hales, B., Friederich, G., Chavez, F., Sabine, C., Watson, A., Bakker, D. C. E., Schuster, U., Metzl, N., Yoshikawa-Inoue, H., Ishii, M., Midorikawa, T., Nojiri, Y., Körtzinger, A., Steinhoff, T., Hoppema, M., Olafsson, J., Arnarson, T. S., Tilbrook, B., Johannessen, T., Olsen, A., Bellerby, R., Wong, C. S., Delille, B., Bates, N. R., and de Baar, H. J. W.: Climatological mean and decadal change in surface ocean $\mathrm{pCO}_{2}$, and net sea-air $\mathrm{CO}_{2}$ flux over the global oceans, Deep-Sea Res. Pt. II, 56, 554-577, 2009.
Tedesco, K., Thunell, R., Astor, Y., and Muller-Karger, F.: The oxygen isotope composition of planktonic foraminifera from the Cariaco Basin, Venezuela: Seasonal and interannual variations, Mar. Micropaleontol., 62, 180-193, 2007.

Toggweiler, J. R. and Sarmiento, J. L.: Glacial to interglacial changes in atmospheric carbon dioxide: the critical role of ocean surface water in high latitudes, in: The carbon cycle and atmospheric $\mathrm{CO}_{2}$ : Natural variations Archean to present, edited by: Sundquist, E. T. and Broecker, W. S., Geoph. Monog. Series 32, American Geophysical Union, Washington, D.C., 163-184, 1985.

Tsuchiya, M., Lukas, R., Fine, A. R., Firing, E., and Lindstrom, E. J.: Source waters of the Pacific Equatorial Undercurrent, Prog. Oceanogr., 23, 101-147, 1989.

Wang, B., Wu, R., and Lukas, R.: Annual adjustment of the thermocline in the tropical Pacific Ocean, J. Climate, 13, 596-616, 2000.

Wang, L.: Isotopic signals in two morphotypes of Globigerinoides ruber (white) from the South China Sea: implications for monsoon climate change during the last glacial cycle, Palaeogeogr. Palaeocl., 161, 381-394, 2000.

Wara, M. W., Ravelo, A. C., and Delaney, M. L.: Permanent El Niño-like conditions during the Pliocene warm period, Science, 309, 758-761, 2005.

Watkins, J. M., Mix, A. C., and Wilson, J.: Living planktic foraminifera in the central tropical Pacific Ocean: Articulating the equatorial "cold tongue" during La Niña, Mar. Micropaleontol., 33, 157-174, 1998.

Wilson, J., Abboud, S., and Beman, J. M.: Primary production, community respiration, and net community production along oxygen and nutrient gradients: Environmental controls and biogeochemical feedbacks within and across "Marine Lakes", Front. Mar Sci., 4, 12, https://doi.org/10.3389/fmars.2017.00012, 2017.

Wyrtki, K.: An estimate of equatorial upwelling in the Pacific, J. Phys. Oceanogr., 11, 1205-1214, 1981. 